Old Dominion University

ODU Digital Commons

CCPO Publications

Center for Coastal Physical Oceanography

1998

\title{
Heat and Salt Changes on the Continental Shelf West of the Antarctic Peninsula Between January 1993 and January 1994
}

John M. Klinck

Old Dominion University, jklinck@odu.edu

Follow this and additional works at: https://digitalcommons.odu.edu/ccpo_pubs

Part of the Hydrology Commons, and the Oceanography Commons

\section{Repository Citation}

Klinck, John M., "Heat and Salt Changes on the Continental Shelf West of the Antarctic Peninsula Between January 1993 and January 1994" (1998). CCPO Publications. 67.

https://digitalcommons.odu.edu/ccpo_pubs/67

\section{Original Publication Citation}

Klinck, J.M. (1998). Heat and salt changes on the continental shelf west of the Antarctic Peninsula between January 1993 and January 1994. Journal of Geophysical Research-Oceans, 103(C4), 7617-7636. doi: 10.1029/98jc00369 


\title{
Heat and salt changes on the continental shelf west of the Antarctic Peninsula between January 1993 and January 1994
}

\author{
John M. Klinck \\ Center for Coastal Physical Oceanography, Old Dominion University, Norfolk, Virginia
}

\begin{abstract}
.
Hydrographic measurements from four cruises between January 1993 and January 1994 over the continental shelf west of the Antarctic Peninsula allow analysis of seasonal changes in heat and salt content of this region. Changes above the permanent pycnocline (about $150 \mathrm{~m}$ ) follow a seasonal pattern of cooling and increasing in salt from summer to winter and warming and freshening from winter to summer. These near-surface changes, expressed as net heating or salting rate, were above $80 \mathrm{~W} \mathrm{~m}^{-2}$ and $4 \mathrm{mg}$ salt $\mathrm{m}^{-2} \mathrm{~s}^{-1}$. The year to year difference was small compared to the seasonal changes. There was no seasonal pattern to the changes below the permanent pycnocline; heat and salt content increased or decreased together, with magnitudes about half $\left(50 \mathrm{~W} \mathrm{~m} \mathrm{~m}^{-2}\right.$ and $2.0 \mathrm{mg}$ salt $\left.\mathrm{m}^{-2} \mathrm{~s}^{-1}\right)$ that observed near the surface. Subpycnocline water warmed $\left(10 \mathrm{~W} \mathrm{~m}^{-2}\right)$ and increased salt $\left(0.5 \mathrm{mg}\right.$ salt $\left.\mathrm{m}^{-2} \mathrm{~s}^{-1}\right)$ from one January to the next. Exchange of Upper Circumpolar Deep Water (UCDW), an oceanic water mass, and West Antarctic Peninsula modified Circumpolar Deep Water, a cooled version of UCDW on the shelf, is responsible for these changes. During the exchange process, UCDW cools by loosing heat to the cold, near-surface Winter Water left by the deep mixing during the previous winter. Subpycnocline heat and salt changes occur as a difference between onshore and vertical diffusion with vertical diffusivities of $(1.0,0.36) \times 10^{-4} \mathrm{~m}^{2} \mathrm{~s}^{-1}$, for heat and salt, respectively, and a horizontal diffusivity of $37 \mathrm{~m}^{2} \mathrm{~s}^{-1}$. The annual change is due to a net flux of UCDW onto the shelf during 1993, with most of the exchange occurring fall and winter. Meandering of the Antarctic Circumpolar Current along the shelf break in this area seems to cause these exchanges. Deep across-shelf cuts in the bottom topography may also play a role.
\end{abstract}

\section{Introduction}

Antarctic continental shelves differ in many respects from Arctic and temperate shelf systems. On average, Antarctic continental shelves are 2 to 2.5 times deeper than other shelves, are characterized by rugged bathymetry, and undergo strong, seasonally varying wind and buoyancy forcing. The latter effect is of particular importance because it modifies the temperature and salinity characteristics of the near-surface water. In some regions, specifically the Ross and Weddell Seas, the strong seasonal forcing is responsible for bottom water formation [Jacobs et al., 1970; Foster and Carmack, 1976; Toole, 1981].

Studies of changes in the heat and salt content of Antarctic waters have been primarily in open ocean re-

\section{Copyright 1998 by the American Geophysical Union.}

Paper number $98 \mathrm{JC} 00369$.

0148-0227/98/98JC-00369\$09.00 gions, such as the Weddell Sea and focused on changes in the mixed layer depth [Gordon and Huber, 1990; Martinson, 1990], seasonal variations in ice cover [Lemke et al., 1990; Owens and Lemke, 1990], and polynya formation [Pease, 1987; Ou, 1988; Grumbine, 1991; Darby et al., 1995]. Moreover, these studies have been confined to specific times and have limited spatial coverage. To date, there have been no studies of seasonal changes in heat and salt content of Antarctic open ocean or continental shelf systems. However, some simple heat and salt budgets have been reported for the Southern Ocean [Gordon, 1981], the open Weddell Sea [Gordon and Huber, 1990], and the continental shelf waters of the Antarctic Peninsula [Smith et al., 1998; Hofmann and Klinck, 1998] and Prydz Bay [Smith and Tréguer, 1994], which show the importance of warm saline Circumpolar Deep Water on heat and salt budgets.

Since 1991 the hydrographic properties of the water overlying the continental shelf west of the Antarctic Peninsula (Figure 1) have been studied as part of a 


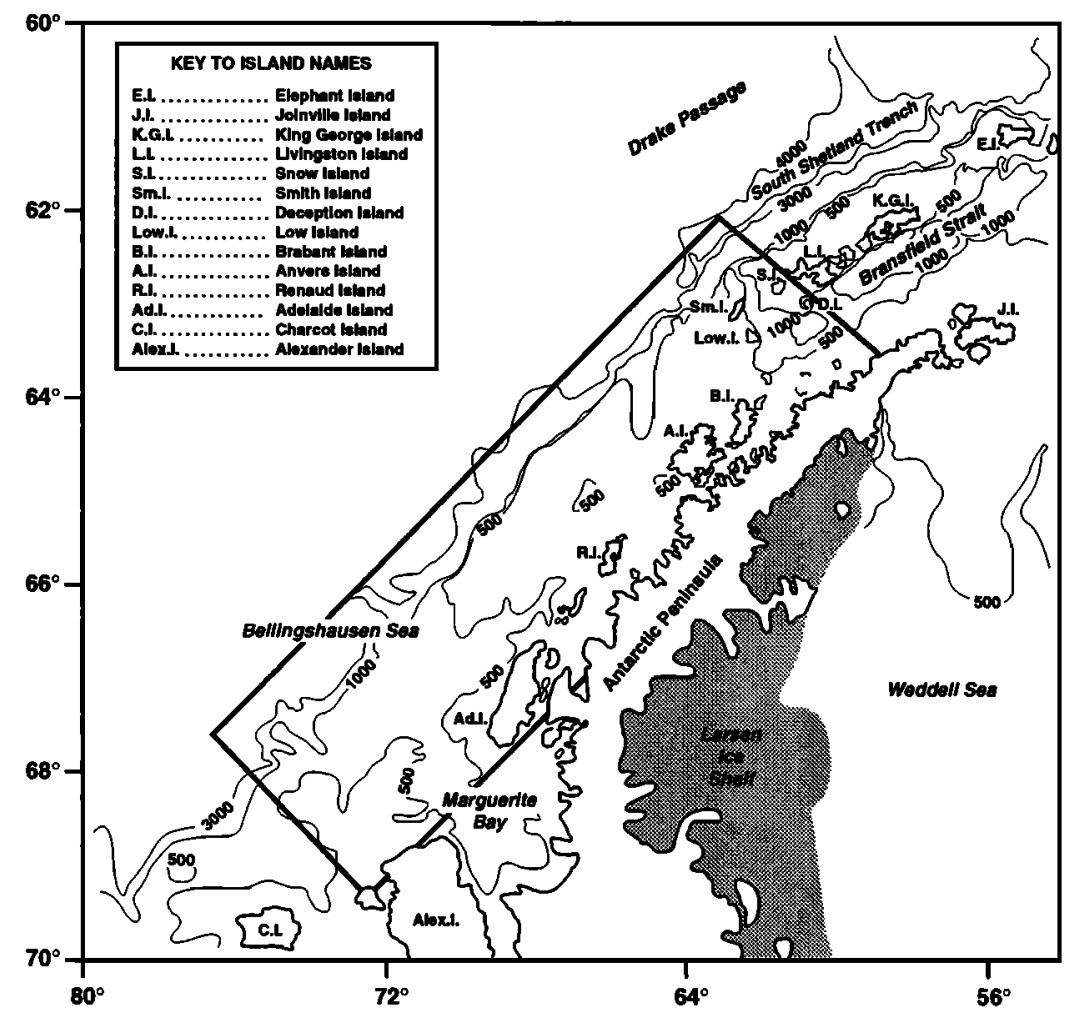

Figure 1. Study region. The heavy lines indicate the area covered by at least one of the cruises. The light lines lines are isobaths for depths of 500, 1000, 2000, 3000, and $4000 \mathrm{~m}$ from ETOPO5.

long-term ecological research (LTER) program [Smith et al., 1995] based at Palmer Station on Anvers Island. Through a series of multidisciplinary cruises, a region of the west Antarctic Peninsula continental shelf (about $200 \mathrm{~km}$ across shelf and $400 \mathrm{~km}$ alongshelf, Figure 2) has been surveyed in all seasons. This comprehensive hydrographic data set provides for the first time a means to investigate seasonal variations in the heat and salt content of these waters. The objective of this study is to estimate the seasonal changes in heat and salt content and to use the estimates to infer circulation and cross-shelf exchanges on the west Antarctic Peninsula continental shelf.

The hydrographic data used in this analysis are described in the following section, which also describes techniques used to calculate the seasonal changes in the heat and salt content. Section 3 presents the resultant across- and along-shelf heat and salt variations. Sections 4 and 5 are a discussion of the results and a summary, respectively.

\section{Data Sources and Methods}

\subsection{Data Calibration and Processing}

The hydrographic observations used in this analysis are from five cruises that took place on the continental shelf west of the Antarctic Peninsula (Figure 2).
The cruises consisted of a series of across-shelf transects with an along-shelf separation of $100 \mathrm{~km}$; along each across-shelf transect, the station spacing was either 10 or $20 \mathrm{~km}$. The designation of stations followed the convention given by Waters and Smith [1992], where a reference point is defined at the intersection of the southernmost across-shelf transect (the 000 Line) and a baseline which defines the inshore extent of the grid. Each across-shelf transect is designated by its distance in kilometers from the $\mathbf{0 0 0}$ Line. Individual stations along an across-shelf transect were designated by their distance in kilometers from the baseline. Thus a station on the 300 Line that is $100 \mathrm{~km}$ from the baseline is referred to as the 300.100 station.

The austral summer cruises in 1993 and 1994 and the 1993 austral winter cruise covered essentially the same part of the region: the 300 to 600 Lines with an acrossshelf station interval of $20 \mathrm{~km}$. The 1993 austral fall cruise covered a larger area (000 to 900 Lines) and had a finer sampling resolution $(10 \mathrm{~km})$ along the transects. The 1991 austral spring cruise covered the smallest area on the grid (500 to 700 Lines).

On the austral spring, summer, and winter cruises, temperature and salinity measurements were made to $500 \mathrm{~m}$ (or to within a few meters of the bottom) with the SeaBird conductivity-temperature-depth (CTD) system on the Bio-Optical Profiling System (BOPS) [Smith et 

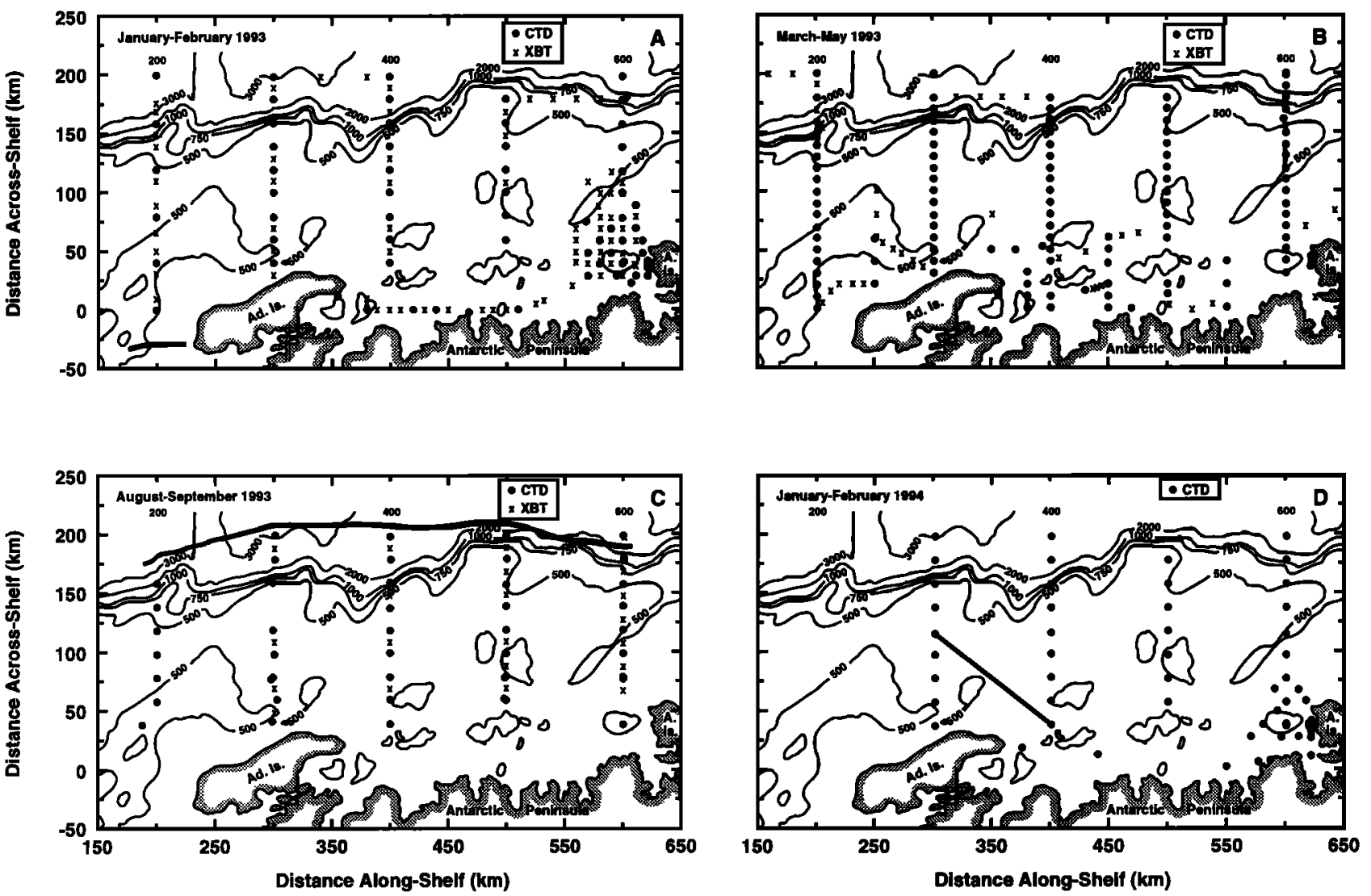

Figure 2. Station locations for each of the four cruises. Shading indicates land. The heavy line shows the location of the ice edge. Light lines are 500, 750, 1000, 2000, and $3000 \mathrm{~m}$ isobaths obtained from ETOPO5. (a) Cruise 93a, (b) cruise 93b, (c) cruise 93c, and (d) cruise 94a. XBT, expendable bathythermograph.

al., 1984]. On the fall cruise, about half of the observations were made with the SeaBird CTD system on the RVIB Nathaniel B. Palmer, which extended the depth range beyond $500 \mathrm{~m}$.

On all cruises, water samples were taken at discrete depths from either Niskin or GoFlo bottles and were analyzed with a guildline salinometer to provide calibrations of the CTD salinity sensors. On the fall cruise, cross-sensor comparisons were performed to ensure that the two CTD systems yield consistent measurements. Additionally, the temperature and conductivity sensors from both CTD systems underwent precruise and postcruise calibrations by SeaBird Electronics. These calibrations, as well as those during the cruise, showed no significant drift in either sensor with either time or depth. Similar results were obtained with the postcruise sensor calibrations from the other cruises. Thus it was not necessary to apply corrections to the temperature and conductivity data. These data were then processed by the procedures and algorithms given by UNESCO [1983] and averaged into $1-\mathrm{m}$ depth bins. Complete descriptions of the sensor calibrations and data processing for the various cruises are given in the technical reports by Lascara et al. [1993a, b], Smith et al. [1993a,b], and Klinck and Smith [1994].

\subsection{Data Interpolation}

The temperature and salinity observations along each across-shelf transect from each cruise were collected into arrays with a $1-\mathrm{m}$ vertical spacing and $10 \mathrm{~km}$ horizontal spacing. The observations in these arrays extended from the surface to the bottom. Some interpolation was required to fill these arrays.

Missing values near the surface were set to the value of the shallowest measurement at that station. In most cases, only the value at the top 1 or $2 \mathrm{~m}$ was missing. At no station were there more that $10 \mathrm{~m}$ of missing values. Some casts had missing values in the interior spanning a range of 1 to $4 \mathrm{~m}$. These values were filled by linear interpolation from the nearest measurements. Horizontal linear interpolation to $10 \mathrm{~km}$ resolution was done for all cruises except the fall cruise. The relatively flat horizontal distributions of temperature and salinity on this shelf (details later) allows this approach. The bottom topography for all sections was taken from mea- 
surements of bottom depth from the fall cruise, which provided the most complete survey of the shelf.

\subsection{Heat and Salt Change and Sensor Accuracy}

The temperature and salinity changes between cruises can be quantified in terms of the heat and salt flux divergence required to produce the observed change. Therefore, at each depth for each station, values of the heating rate $\left(Q\right.$ in units of $\left.\mathrm{W} \mathrm{m}^{-3}\right)$ and the salting rate $(R$ in units of $\mu \mathrm{g}$ salt $\mathrm{m}^{-3} \mathrm{~s}^{-1}$ ) are calculated as

$$
Q=\frac{\rho_{o} c_{p} \Delta T}{\Delta t} \quad R=\frac{\rho_{o} \Delta S}{\Delta t},
$$

where $\rho_{o}$ is the reference density $\left(1028 \mathrm{~kg} \mathrm{~m}^{-3}\right), c_{p}$ is the specific heat (3987 $\left.\mathrm{J} \mathrm{kg}^{-1}{ }^{\circ} \mathrm{C}^{-1}\right), \Delta T$ is the temperature change, $\Delta S$ is the salinity change, and $\Delta t$ is the time interval between occupations of a station. For stations on different cruises, the time difference is calculated from the time of the midpoint of the section in which the station occurs (all sections were completed in 2 to 3 days) and ranged from 80 to 150 days (Tables 1 , 2).

The lower limit on meaningful heat and salt fluxes is set by the accuracy of the CTD sensors. A thermistor accuracy of $0.005^{\circ} \mathrm{C}$, which is appropriate for the SeaBird sensor, is equivalent to a heat change of 0.0126 $\mathrm{W} \mathrm{m} \mathrm{m}^{-3}$ over 180 days. That is, if there were really no temperature change but the measurements were different due to inaccuracy of the sensor, then the above heat flux would be estimated when in fact there had been none. Similarly, a salinity sensor accuracy of 0.005 is equivalent to $0.33 \mu \mathrm{g}$ salt $\mathrm{m}^{-3} \mathrm{~s}^{-1}$ over 180 days. These fluxes approximately double for the shortest time between cruises ( 80 days). All fluxes estimated from the stations considered here are at least an order of magnitude larger than these minimum fluxes.

\subsection{Effect of Internal Wave Aliasing}

In the waters overlying the west Antarctic Peninsula continental shelf, the largest variability in water mass structure occurs in the upper $150 \mathrm{~m}$ [Hofmann et al., 1996; Smith et al., 1998; Hofmann and Klinck, 1998]. The permanent pycnocline occurs between 150 and $200 \mathrm{~m}$ (details later). One concern in these cal- culations of heat and salt changes between cruises is that high-frequency variability (e.g., internal waves) are interpreted as seasonal changes. To some extent, this bias is eliminated by integrating the changes over depth. The importance of high-frequency changes is investigated with stations that were repeated within a few hours (2 to 4) during a single cruise. For these repeat casts, the change in temperature and salinity is calculated at each depth and the maximum absolute and the root-mean-square (rms) variation over the whole cast was determined (Table 3 ).

During the spring, summer 1993 and winter cruises, 18,49 and 17 stations, respectively, were repeated. The number of repeat casts at a given station ranged from 2 to 15 , with most stations being sampled 4 to 6 times ('Table 3). During a given cruise, the upper bound ch the rms variability of temperature and salinity was $0.5^{\circ} \mathrm{C}$ and 0.1 , respectively (Figure 3 ). This variability between repeat casts was about the same for all cruises and is much less than the changes observed between cruises (Figure 3). The overlap of rms values on within-cruise differences and between-cruise differences is small. This analysis indicates that high-frequency variations are not a significant source of aliasing in the heat and salt flux calculations.

The issue of aliasing of mesoscale variations, with timescales of days and weeks is harder to quantify. It may be that water changes position every week or so and the cruises sample these swings at random states. I have no data at these time separations on which to base any analysis. However, water properties on this shelf have been measured on a number of occasions and are always found to have similar properties except for seasonal changes near the surface. Having no way to quantify these sampling problems, I assume, perhaps incorrectly, that the cruises are measuring longer period changes in the water properties.

\subsection{Sea Ice}

This continental shelf has a seasonally varying ice cover being ice free in summer and ice covered in winter. The variability in ice cover is considered by Stammerjohn and Smith [1996], which was based on passive microwave observations from SMMR and SSM/I satellitebased sensors. They find that ice cover develops rapidly from May to July, reaches a peak in August, and de-

Table 1. Summary of the Information From Cruises That Provide Hydrographic Measurements Used in This Study

\begin{tabular}{lcrcc}
\hline Cruise & Dates & Stations & Sensors & Lines Sampled \\
\hline 91a & Nov. 7 - 21, 1991 & 44 & BOPS & $500-700$ \\
93a & Jan. 8 to Feb. 7, 1993 & 150 & BOPS & $200-600$ \\
93b & Mar 25 to May 15, 1993 & 225 & BOPS+CTD & $000-900$ \\
93c & Aug. 23 to Sept. 30,1993 & 55 & BOPS & $200-600$ \\
$94 a$ & Jan. 11 to Feb. 7, 1994 & 72 & BOPS & $300-600$ \\
\hline
\end{tabular}


Table 2. Year-day for the Midpoint of Each Section for Each Cruise.

\begin{tabular}{lrrrrr}
\hline & \multicolumn{5}{c}{ Line } \\
\cline { 2 - 6 } Cruise & 600 & 500 & 400 & 300 & 200 \\
\hline & 10 & 13 & 28 & 32 & 34 \\
$93 \mathrm{a}$ & 104 & 106 & 107 & 111 & 114 \\
$93 \mathrm{~b}$ & 244 & 249 & 254 & 259 & 265 \\
$93 \mathrm{c}$ & 16 & 13 & 32 & 35 & $\ldots$ \\
$94 \mathrm{a}$ & & & & & \\
\hline
\end{tabular}

clines slowly from September to January, reaching a minimum in February. This pattern of rapid development and slow retreat is the opposite of all other sectors around Antarctica [Stammerjohn and Smith, 1996].

In particular, 1991 and 1992 were years of higher than average ice cover while 1993 was a year of lower than average ice cover [Stammerjohn and Smith, 1996, Figure 4]. Furthermore, coherence analysis of ice cover anomalies indicates that there is propagation from the Bellingshausen Sea to the Peninsula (no other region has a similar coherence).

Ice cover during the cruises was typical. No sea ice was encountered during the March-May 1993 cruise. Ice covered the entire shelf during the August-September 1993 cruise, except for one station (Figure 2). The area was ice free in January-February 1993; there was some ice cover in the southern part of the domain in JanuaryFebruary 1994.

Ice cover changes year to year but tends to be higher or lower than average in two consecutive years [Stammerjohn and Smith, 1996]. There is a 5-7 year periodicity in ice cover. This variation is likely related to a propagating phenomenon, dubbed the Antarctic Circumpolar Wave [White and Peterson, 1996], which produces anomalies of sea level pressure, wind stress, surface temperature, and sea ice extent that propagate eastward at a rate sufficient to circle the Southern Ocean in 8 to 10 years. The phase of these anomalies is such that in 1993 conditions west of the Antarctic Peninsula were characterized by high sea surface temperature, southward meridional winds and low sea ice extent. The low sea ice coverage over this region in 1993 was verified with satellite-derived measurements [Stammerjohn and Smith, 1996, Figure 5].

\subsection{Winds}

Two wind climatologies are used to characterize the annual average winds over the west Antarctic peninsula continental shelf. The monthly wind stress climatology over a coarse grid (2.5 of latitude and longitude) [Trenberth et al., 1990] is based on the European Centre for Medium-Range Weather Forecasts analysis for the years 1980 to 1986 . The annual mean wind stress is northwesterly with a strength of $0.06 \mathrm{~N} \mathrm{~m}^{-2}$. Over the shelf, the winds weaken during the summer and turn more northerly. During the fall and winter the winds strengthen to $0.1 \mathrm{~N} \mathrm{~m}^{-2}$.

Three grid points from this climatology are used to estimate the Ekman transport for this shelf. Only one point is over the shelf $\left(65^{\circ} \mathrm{S}, 67.5^{\circ} \mathrm{W}\right)$, but it has good values only for the months of January through May. Assuming a mixed layer depth of $150 \mathrm{~m}$ (justified later), the annual mean Ekman flow is $0.02 \mathrm{~m} \mathrm{~s}^{-1}$ toward $65^{\circ} \mathrm{T}$, with speeds varying from 0.015 to $0.028 \mathrm{~m} \mathrm{~s}^{-1}$ and directions varying from $38^{\circ}$ to $99^{\circ} \mathrm{T}$. The coastline orientation in this area is about $50^{\circ} \mathrm{T}$. Two other points are just off the shelf: $65^{\circ} \mathrm{S}, 70^{\circ} \mathrm{W}$ (southern shelf) and $62.5^{\circ} \mathrm{S}, 65^{\circ} \mathrm{W}$ (northern shelf). At the southern point the Ekman flow is $0.023 \mathrm{~m} \mathrm{~s}^{-1}$ towards $59^{\circ} \mathrm{T}$; at the northern point, the flow is $0.037 \mathrm{~m} \mathrm{~s}^{-1}$ towards $18^{\circ} \mathrm{T}$.

Table 3. For Each Case Where Repeat Casts Were Made Within a Few Hours (in Most Cases Between 2 and 4 Hours), the $T$ and $S$ Changes Between Casts Were Calculated

\begin{tabular}{|c|c|c|c|c|c|c|c|c|}
\hline Cruise & Station & Casts & Maximum & Depth, m & rms & Maximum & Depth, m & rms \\
\hline $93 a$ & 600.180 & 14 & 1.175 & 62 & 0.441 & 0.113 & 67 & 0.049 \\
\hline $93 a$ & 600.040 & 15 & 0.866 & 49 & 0.291 & 0.210 & 1 & 0.053 \\
\hline $93 a$ & 500.080 & 2 & 1.203 & 86 & 0.301 & 0.082 & 87 & 0.023 \\
\hline $93 a$ & 400.160 & 9 & 0.620 & 84 & 0.266 & 0.080 & 171 & 0.034 \\
\hline $93 a$ & 400.060 & 9 & 0.969 & 88 & 0.372 & 0.131 & 154 & 0.055 \\
\hline $93 c$ & 600.080 & 4 & 0.774 & 93 & 0.248 & 0.207 & 89 & 0.084 \\
\hline $93 c$ & 500.080 & 5 & 0.596 & 107 & 0.207 & 0.202 & 1 & 0.104 \\
\hline $93 c$ & 400.080 & 3 & 1.454 & 117 & 0.455 & 0.301 & 120 & 0.102 \\
\hline $93 c$ & 200.160 & 5 & 0.912 & 104 & 0.232 & 0.433 & 109 & 0.125 \\
\hline 91a & 700.160 & 4 & 1.200 & 156 & 0.321 & 0.193 & 106 & 0.068 \\
\hline $91 \mathrm{a}$ & 607.040 & 6 & 0.341 & 118 & 0.160 & 0.074 & 45 & 0.035 \\
\hline $91 \mathrm{a}$ & 600.040 & 4 & 0.392 & 47 & 0.090 & 0.092 & 47 & 0.024 \\
\hline $91 \mathrm{a}$ & 500.120 & 4 & 0.234 & 183 & 0.085 & 0.062 & 121 & 0.021 \\
\hline
\end{tabular}

Differences were characterized at each cast by the maximum absolute difference and root-mean-square (rms) difference. The depth entry gives the depth in meters at which the maximum absolute change occurs. The values in the table are the largest measure of temperature and salinity difference for all of the casts at a given station is shown. All other rms values for a given stations were within a factor of 2 of the given value. 


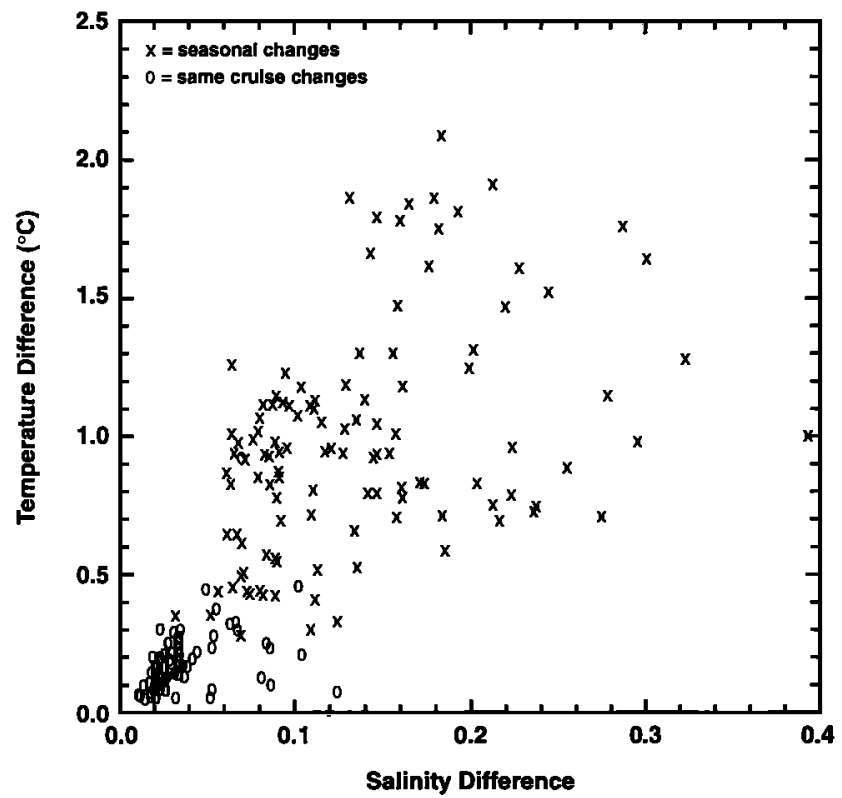

Figure 3. Root-mean-square (rms) change of hydrographic conditions between two casts at the same station. For each pair of casts, the rms difference in temperature $\left({ }^{\circ} \mathrm{C}\right)$ and salinity is used to locate a point on the diagram. Differences from casts separated by a few hours during the same cruise are denoted by an open circle, while those from casts at a given station but from different cruises, separated by 3 or more months, are denoted by a cross.

Only this third point has wind stress for each month of the year. The winds in this region drive Ekman flow more or less parallel to the coastline at relatively slow speeds. The cross shelf component of Ekman flow is no larger than $0.01 \mathrm{~m} \mathrm{~s}^{-1}$, and may be either upwelling or downwelling favorable. These cross-shelf transports are consistent with an average vertical pumping over the shelf of around $1 \mathrm{~m} \mathrm{~d}^{-1}$ (assuming $150 \mathrm{~km}$ wide shelf). Ekman pumping is larger during the stronger wind events, but still represents relatively weak flows.

A second wind product based on the ERS 1 scatterometer [Katsaros and Pouliquen, 1996] with a spatial resolution of $1^{\circ}$ latitude and longitude and a time resolution of 1 week indicates three dominant patterns over the shelf: westerlies, northeasterlies, and northerlies. On rare occasions, the winds are northwesterlies with weekly means greater than $15 \mathrm{~m} \mathrm{~s}^{-1}\left(0.3 \mathrm{~N} \mathrm{~m}^{-2}\right)$. Northeasterly winds drive downwelling, but the onshore flow speed would be low (a few $\mathrm{cm} \mathrm{s}^{-1}$ ) given the thick mixed layer. The westerlies and northerlies drive upwelling and downwelling, respectively, but the rates are low given the partial onshore direction of the winds.

Even though wind stress seems to have a weak influence on the circulation, it is clearly important in moving ice. Ice cover advances and retreats with timescales of a few days (for example, reports from Palmer Station in the Antarctic Journal of the United States) which are clearly due to surface wind stress.

\subsection{Circulation}

Estimates of near-surface flow are obtained from estimates of surface wind stress (see above). However, the circulation below the mixed layer is poorly known. It would be thought, given the deep water over this shelf, that dynamic calculations would yield estimates of circulation. However, the water over this shelf is weakly stratified and the isopycnals (controlled largely by salinity) are horizontal (discussed later). Estimates of geostrophic circulation below the mixed layer were sufficiently noisy that they can not be contoured, except for the fall 1993 cruise [Hofmann and Klinck, 1998]. All estimates are consistent with a general cyclonic baroclinic circulation on this shelf with speeds of a few $\mathrm{cm}$ $\mathrm{s}^{-1}$. This pattern of circulation is consistent with what might be expected with the Antarctic Circumpolar Current (ACC) flowing northeastward along the shelf break and with downwelling winds along the shelf. No direct observations of flow speed over this shelf have been analyzed to improve this simple cartoon of the circulation.

\section{Results}

The changes in water properties between consecutive cruises will be described in the sections below. In order to have a context in which to evaluate these changes, the expected water structure will be described first. After the overview, the property changes from the four cruises between January 1993 and January 1994 will be discussed. Finally, a measure of interannual variation is estimated from the change between January cruises separated by one year. This analysis attempted to characterize the changes in water characteristics from winter to spring using data from the spring 1991 cruise, but these results are not included for two reasons. The coverage in 1991 was limited (Table 1). Also, interannual variability (discussed below) of the water mass structure, especially below the mixed layer, makes seasonal comparisons difficult for cruises separated by more than a year.

\subsection{Water Masses in the Peninsula Region}

The water mass structure on the west Antarctic Peninsula continental shelf is relatively simple [Hofmann et al., 1996; Smith et al., 1998] and is similar to that observed in other Antarctic continental shelves [Hofmann and Klinck, 1997]. Temperature and salinity along the 600 Line in summer (Figure 4) and winter (Figure 5) are shown as examples of hydrographic conditions in this area during extreme seasons. Water masses in this region (Figure 6) are then identified. Other sections from these cruises and sections from other cruises are similar to the examples shown. The references above contain additional sections from various cruises.

The isotherms in the summer are largely horizontal across the shelf (Figure 4a) revealing three regions: a surface warm layer $\left(T>0.5^{\circ} \mathrm{C}\right)$, a layer of cold water 

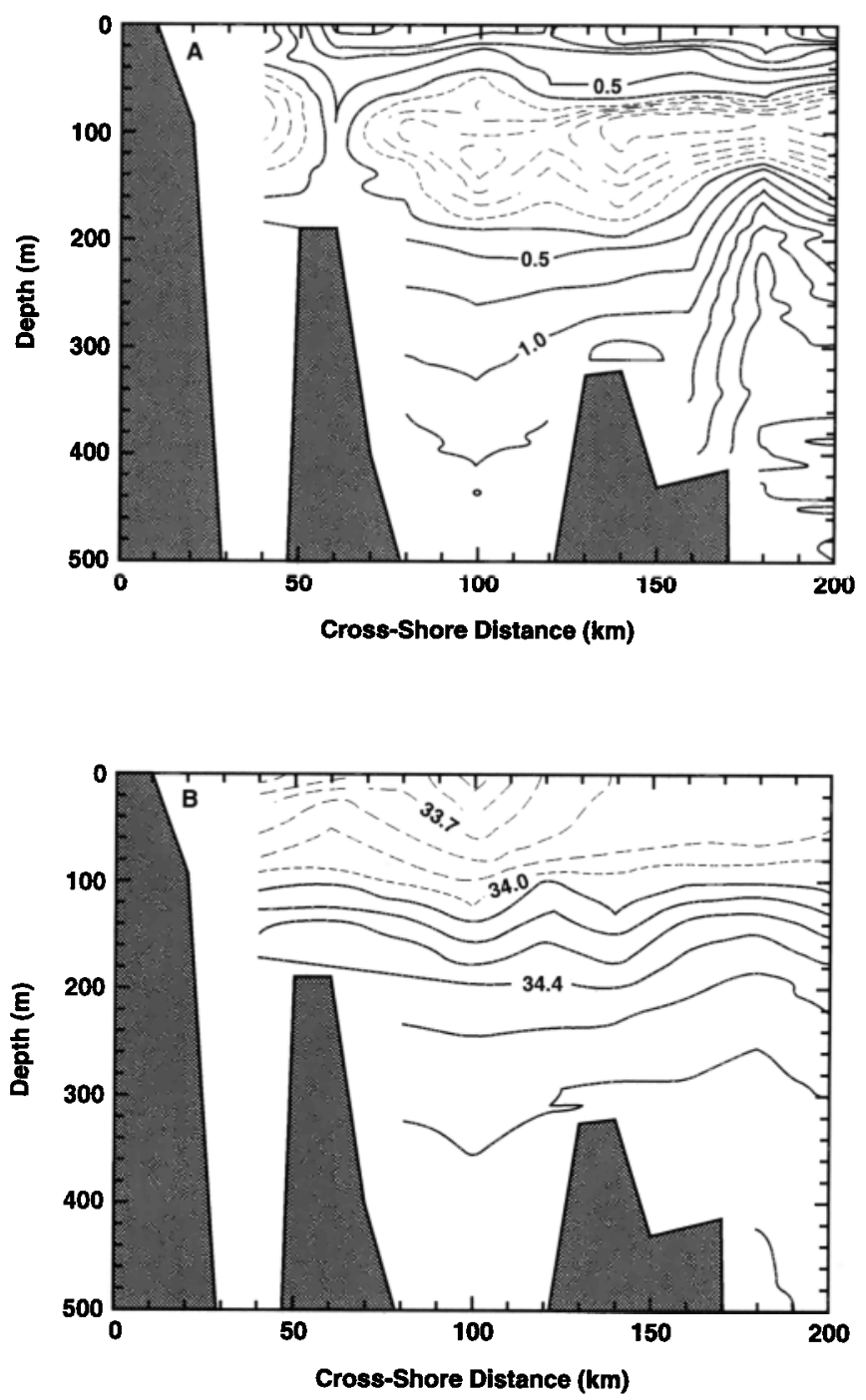

Figure 4. Temperature and salinity along the 600 Line measured during the January 1993 (93a) cruise. Observations were taken every $20 \mathrm{~km}$ along this section. The heavy line is the bottom topography as constructed from the depth at the stations measured during cruise 93b. (a) Temperature contour intervals are $0.25^{\circ} \mathrm{C}$ for temperatures between $-2.0^{\circ}$ and $1.0^{\circ} \mathrm{C}$ and $0.2^{\circ} \mathrm{C}$ for temperatures above $1.0^{\circ} \mathrm{C}$. Dashed contours indicate temperatures below $0.0^{\circ} \mathrm{C}$, while those above are indicated by solid contours. Short dashed lines indicate the $0.0^{\circ} \mathrm{C}$ contour. (b) The salinity contour interval is 0.1 , with salinity (practical salinity units, psu) above 34.0 indicated by solid lines. Salinity below 34.0 is indicated by dashed lines. The short dashes show the 34.0 contour.

$\left(T<-0.5^{\circ} \mathrm{C}\right)$ and a subpycnocline layer of warmer water $\left(T>0.5^{\circ} \mathrm{C}\right)$. The highest temperatures $\left(T>1.5^{\circ} \mathrm{C}\right)$ occur at and offshore of the shelf break. Isohalines in the summer are also level (Figure $4 \mathrm{~b}$ ) with a continuous increase in salinity from surface to the bottom (at these temperatures, salinity determines density). The strongest gradients of salinity occur between 100 and $200 \mathrm{~m}$, which is the pycnocline.
Temperature and salinity are not markedly different during the winter except near the surface. Isotherms (Figure 5a) and isohalines (Figure 5b) are level except far offshore. Pack ice covered the entire shelf except for the one station at the offshore end of this section; the downwarp of isolines is due to deeper mixing or offshore displacement of the ACC. Surface temperatures (Figure 5a) down to $50 \mathrm{~m}$ are near freezing $\left(-1.8^{\circ} \mathrm{C}\right)$. From 50 to $150 \mathrm{~m}$, temperatures increase to about $0.5^{\circ} \mathrm{C}$, with the water becoming warmer towards the bottom. Water at the shelf break is above $1.5^{\circ} \mathrm{C}$. Salinity increases with depth (Figure $5 \mathrm{~b}$ ) below a mixed layer to $50 \mathrm{~m}$. The salinity at the surface is higher than in the summer but the isohalines are horizontal except for some structure at the shelf break. The base of the pycnocline is a little higher during the winter cruise (about $130 \mathrm{~m}$ ).

These two sections from different cruises are examples of the structure of temperature and salinity over this shelf region. Other sections from this and other cruises have the same appearance (figures not shown).
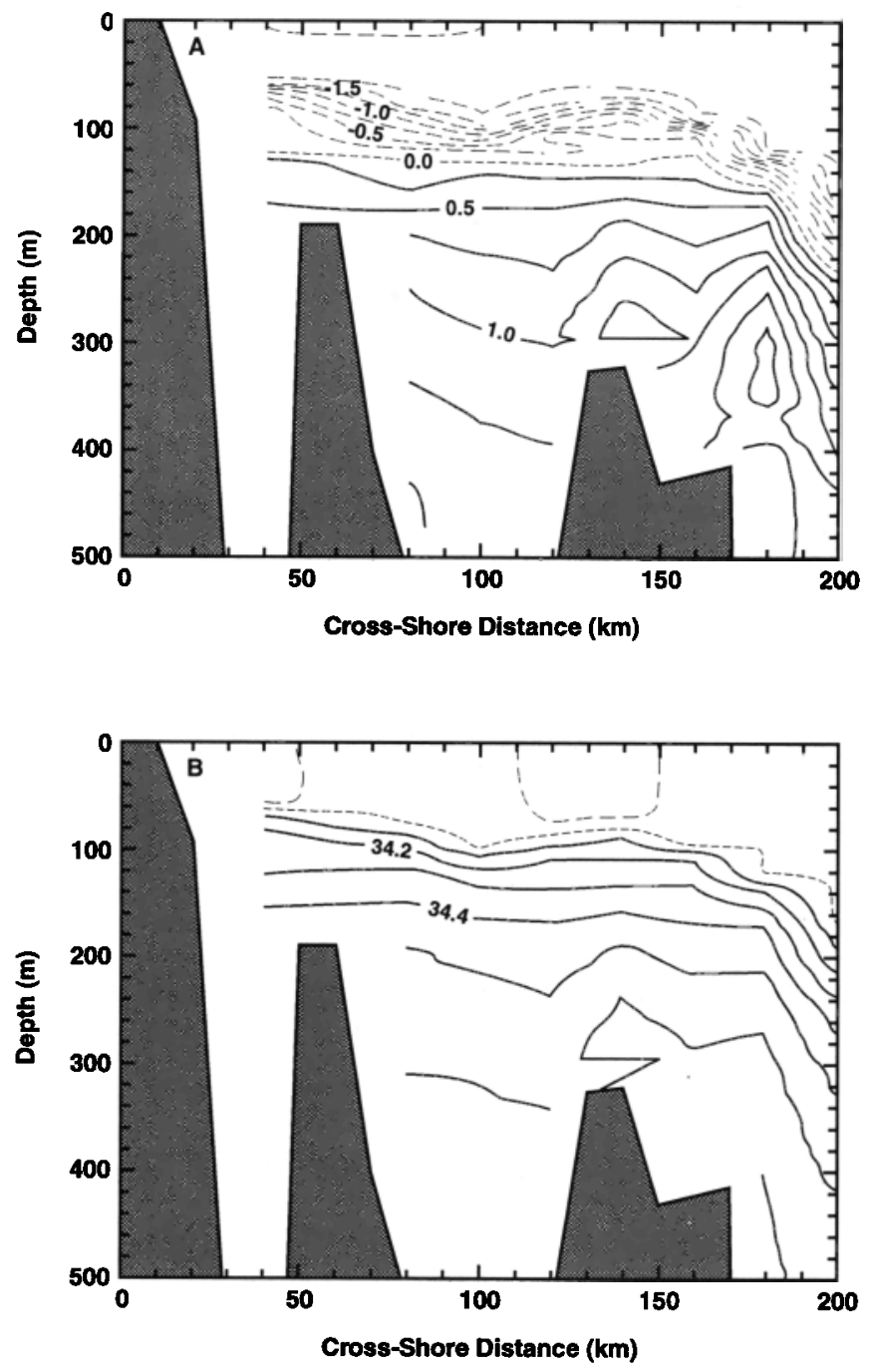

Figure 5. Same as Figure 4 except for measurements taken during the August-September 1993 (93c) cruise. Observations were taken every $20 \mathrm{~km}$ along this section. 

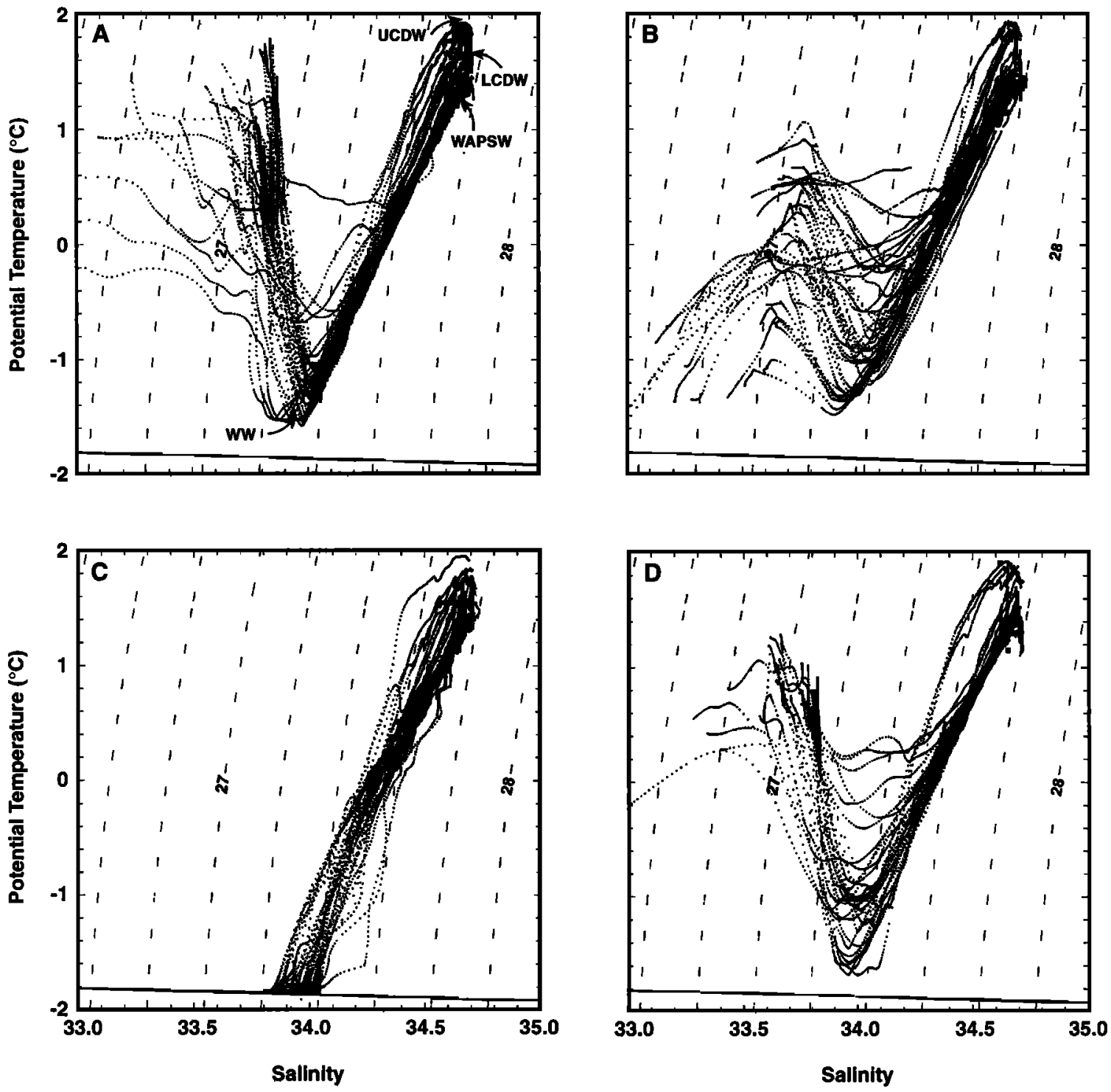

Figure 6. Temperature-salinity diagrams for each of the cruises. These diagrams use observations that have been interpolated vertically and horizontally as described in the text. Dashed lines on the figure indicate density $\left(\sigma_{t}\right)$ at $0 \mathrm{dbar}$ for the indicated temperature and salinity. The solid line near the bottom of the figure is the freezing point. (a) Cruise 93a, (b) cruise 93b, (c) cruise 93c, and (d) cruise 94a. WAPSW, West Antarctic Peninsula Shelf Water.

Due to this horizontal uniformity, is it possible to interpolate all cruise data to $10 \mathrm{~km}$ horizontal spacing, which is the highest data density from these cruises, without significantly changing the results of this analysis.

The basic structure of the water below the permanent pycnocline (Figure 6) is set by three forms of Circumpolar Deep Water (CDW). Upper CDW (UCDW) is defined by a temperature maximum $\left(T>1.5^{\circ} \mathrm{C}\right)$ and salinity between 34.6 and 34.7. Lower CDW (LCDW) is characterized by a salinity maximum (34.72) but is cooler than UCDW $\left(1.3^{\circ}\right.$ to $\left.1.6^{\circ} \mathrm{C}\right)$. These water masses overlie one another and are transported northeastward with the ACC. The core of the shallower water mass (UCDW) is found near the continental shelf break at about $500 \mathrm{~m}$ (Figures 4 and 5) throughout the west
Antarctic Peninsula region, while the deeper water mass (LCDW) is found at depths greater than $800 \mathrm{~m}$, which is below the maximum depth included in this analysis. The high relative temperature of UCDW is useful in locating the southern edge of the ACC (Figures 4 and 5)[Orsi et al., 1995]. A cooled form of UCDW, called West Antarctic Peninsula modified CDW (or WAP Shelf Water, for short), is found over the shelf. This water has temperatures in the range $1.0^{\circ}$ to $1.45^{\circ} \mathrm{C}$ and is distinguished from LCDW by its lower salinity (Figure 6). For a more complete discussion of these water masses, see Smith et al. [1998].

UCDW is cooled on the shelf by heat exchange across the permanent pycnocline with the cold near-surface Antarctic Surface Water (AASW), which in winter has 
temperatures near freezing $\left(-1.8^{\circ} \mathrm{C}\right)$ at a salinity ranging from 33.8 to 34.1 (Figures 5 and $6 \mathrm{c}$ ). A part of this water remains below $-1.0^{\circ} \mathrm{C}$ and is referred to as Winter Water (WW) [Toole, 1981]. During summer, the top 10 to $30 \mathrm{~m}$ warms and freshens (Figures $4,6 \mathrm{a}$, and $6 \mathrm{~d}$ ).

The change of water characteristics between seasons is evident in the summer-to-fall transition (Figures 6a and $6 \mathrm{~b}$ ). The surface water cools and wind mixing deepens the mixed layer to erode the seasonal surface structure. In the transition to winter (Figures $6 \mathrm{~b}$ and $6 \mathrm{c}$ ), the upper water column is cooled to the freezing point, and AASW is quite uniform except for some variation in salinity (33.8 to 34.1 )(Figure 5). The surface water again warms and freshens in the return to summer (Figures 6c and 6d). Water below the permanent pycnocline is isolated from seasonal changes in forcing so neither UCDW nor WAP Shelf Water undergo seasonal variation (Figure 6).

The hydrographic measurements from the January 1993 and January 1994 cruises provide evidence for interannual variations in the water properties (Figures 6a and 6d). Surface waters in January 1993 (Figure 6a) are warmer and saltier than those in January 1994 (Figure 6d). However, the spatial variability in temperature and salinity was larger in January 1993. In January 1994 there was extensive erosion of AASW which was not evident in 1993. Furthermore, WW in January 1994 was colder and saltier than in January 1993. Finally, in January 1994, there was a clear separation of UCDW and WAP Shelf Water which is not evident in January 1993.

These observations imply that more ice melted in spring 1993 (before the January 1994 cruise) compared to spring 1992 (before the January 1993 cruise), which created fresher, cooler surface waters in summer 1994 than in summer 1993. There could also have been more precipitation and less surface heating in spring 1993. Furthermore, the spring winds were likely to have been stronger in 1993 (compared to 1992) which provide energy for deep mixing to erode AASW layer in spite of the stronger salinity contrast across the pycnocline. More ice seems to have been created in winter 1993 than winter 1992 since WW was colder and saltier in summer 1994 compared to summer 1993. Finally, a clear separation of UCDW and WAP Shelf Water in 1994 suggests an exchange of water across the shelf break in late 1993. That is, UCDW moved over the west Antarctic Peninsula shelf during late 1993 displacing WAP Shelf Water. The implications of these observations will be discussed more fully after more detailed analysis of the seasonal and interannual hydrographic changes.

\subsection{Water Property Changes Over 1993:}

3.2.1. Vertical Structure. The vertical structure of the changes in the water column are displayed along the 600 Line. Similar changes occur along other lines, but figures are not shown in the interest of brevity. At
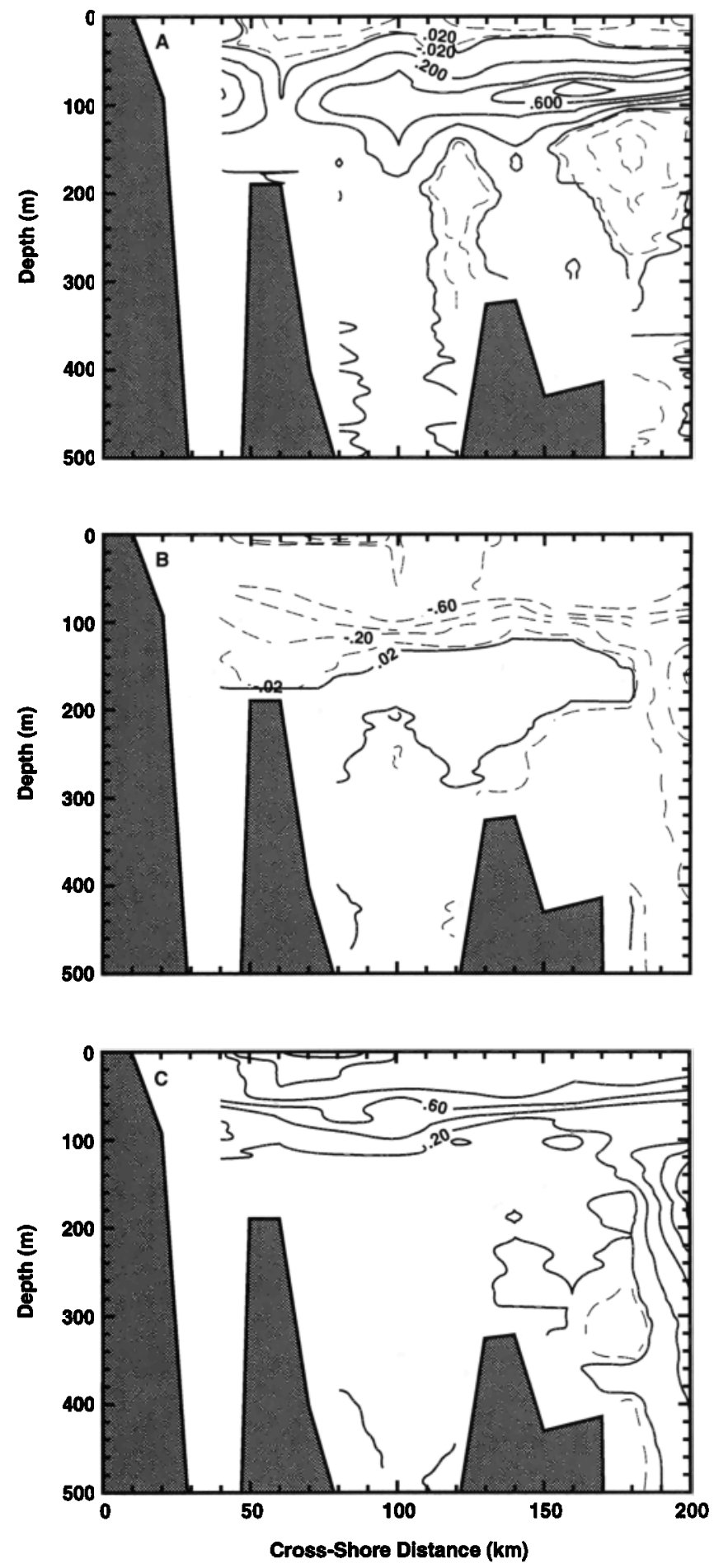

Figure 7. Temperature change along the 600 Line. Temperature changes are displayed in units of heating rate $\left(\mathrm{W} \mathrm{m}^{-3}\right)$. The contour interval is 0.2 ; solid lines indicate heating and long dashed lines indicate cooling. Two additional contours at \pm 0.02 indicate the area over which significant temperature changes occur. The heavy line is the bottom topography as constructed from the depth at the stations measured during cruise 93b. (a) Temperature change between cruises 93a and 93b. (b) Temperature change between cruises $93 \mathrm{~b}$ and 93c. (c) Temperature change between cruises $93 \mathrm{c}$ and 94a. 
the northern end of the study region the temperature change (Figure 7a) from summer to fall (cruises 93a to $93 \mathrm{~b}$ ) is negative in the surface layer resulting from the breakdown of the summer seasonal pycnocline. The water has become warmer between the seasonal and permanent pycnoclines (between 50 and $150 \mathrm{~m}$ ). Below $150 \mathrm{~m}$ on the outer continental shelf, cooling occurs at about $140 \mathrm{~km}$ and at the shelf break. The magnitude of the cooling at the shelf break is larger than in the surface layers or over the shelf. The southern boundary of the ACC and associated UCDW has moved away from the shelf break [Klinck, 1997] being replaced by colder water either from below or from the shelf.

The progression from fall to winter (Figure $7 \mathrm{~b}$ ) is accompanied by further cooling of the mixed layer and renewal of WW down to about $140 \mathrm{~m}$. Cooling offshore of the shelf break indicates the continued offshore deflection of the ACC. Across the continental shelf, the water below the permanent pycnocline warms at middepths and cools below. This pattern suggests upward displacement of the deep and warmer shelf water which is being displaced by alongshore movement of colder, denser WAP Shelf Water.

From winter to summer the whole shelf warms, except for small amounts of cooling at the shelf break (Figure 7c). The surface layer is warmed considerably down to $100 \mathrm{~m}$ with the largest changes at the surface in the inner shelf. Warming at the shelf edge indicates that the ACC and UCDW has returned to the shelf break.

The summer to fall salinity change at the northern part of the study area (Figure 8a) is characterized by a reduction in salinity everywhere above $200 \mathrm{~m}$ except in the near surface waters on the middle and inner shelf. The salinity decrease at the shelf break coincides with the temperature decrease (Figure 7a). The presence of fresher water at $120 \mathrm{~km}$ suggests an isolated eddy of higher salinity and warmer water (UCDW) over the shelf in the summer that is not present in the fall. Similarly, the large salt change at the surface over the inner and middle shelf results from a low-salinity lens in the summer that is gone by fall. The increase in salt with depth is coincident with warming, indicating an increased contribution of UCDW.

From fall to winter, the water column across the shelf above $250 \mathrm{~m}$ increases in salinity (Figure 8b), with the largest change at the base of the winter mixed layer. The reduction in salinity at the shelf edge is due to the offshore shift of the ACC. Over the shelf, the deeper waters decrease in salinity which is consistent with cooling for the same time period (Figure 7b), due to replacement by WAP Shelf Water.

From winter to summer the salinity decreases above $80 \mathrm{~m}$ and increases below $100 \mathrm{~m}$ (Figure $8 \mathrm{c}$ ). The strongest freshening at the surface occurs along the inner part of the shelf where warming is also the greatest. The salinity increases below $100 \mathrm{~m}$ (the base of the winter mixed layer) due to ice production after the time
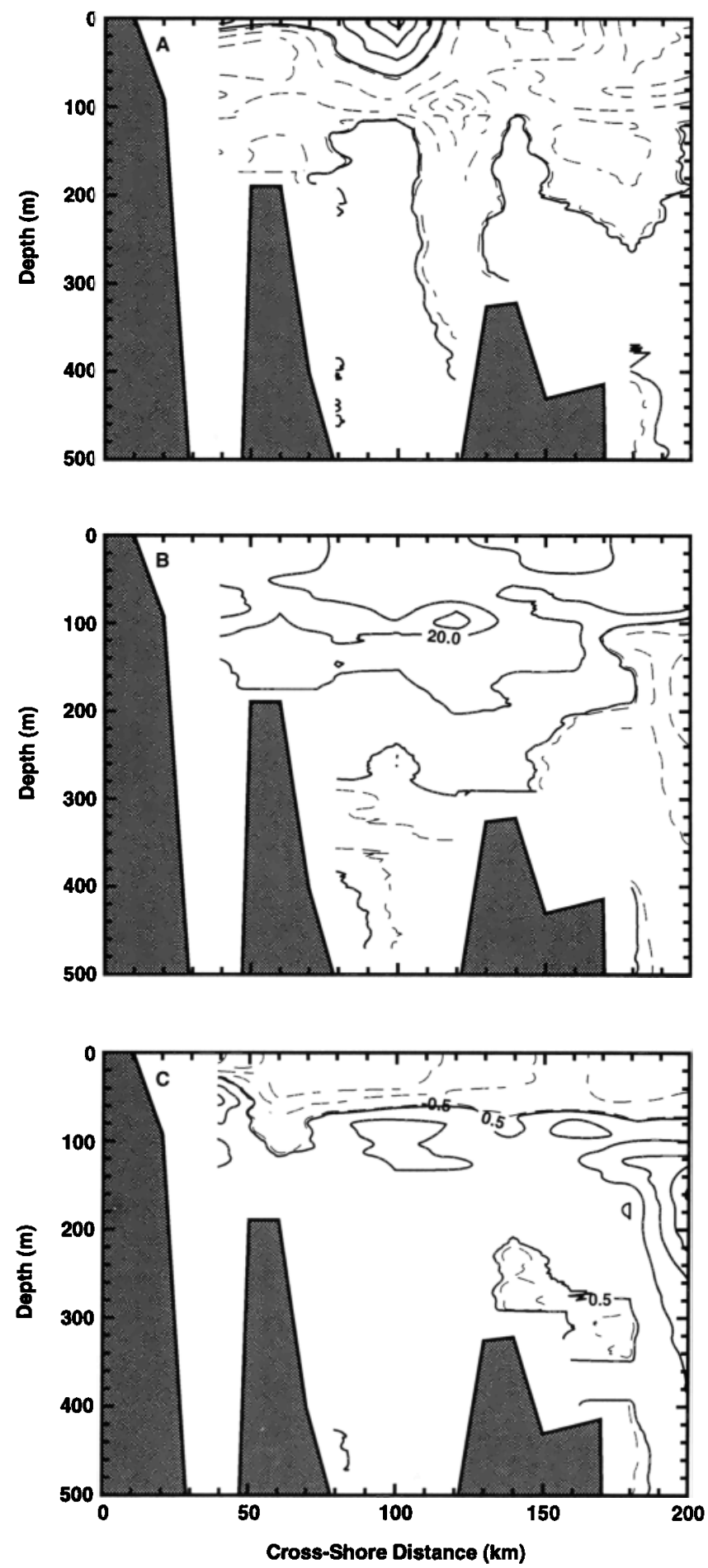

Figure 8. Salinity change along the 600 Line. Salinity change is displayed as the salting rate $\left(\mu \mathrm{g} \mathrm{salt} \mathrm{m}^{-3} \mathrm{~s}^{-1}\right)$. The contour interval is 10.0; solid lines are drawn for an increase in salt content, and long dashed lines are drawn for a decrease. Two additional contours at \pm 0.5 locate the smallest significant salinity changes. The heavy line is the bottom topography as constructed from the depth at the stations measured during cruise 93b. (a) Salinity change between cruises 93a and 93b. (b) Salinity change between cruises $93 \mathrm{~b}$ and $93 \mathrm{c}$. (c) Salinity change between cruises 93c and 94a. 
covered by the winter measurements (ice cover developed late in this area in 1993 [Stammerjohn and Smith, 1996]).

3.2.2. Horizontal Structure. The spatial pattern of heat and salt changes is succinctly depicted with the vertical integral of these quantities above $150 \mathrm{~m}$ and below the permanent pycnocline $(150 \mathrm{~m}$ to $500 \mathrm{~m}$ or the bottom). The first depth range includes the variability in AASW above the permanent pycnocline, while the second interval includes variations of UCDW and WAP Shelf Water below the permanent pycnocline. Note that the vertical integral of the heat flux divergence is equivalent to the net heat or salt flux over a column of fluid with an area of $1 \mathrm{~m}^{2}$ and extending over the depth range indicated. These integrated values can be thought of as the net surface flux required to make the observed change. This conversion is merely for interpretation; I do not claim that all changes are due to fluxes at the ocean-atmosphere interface. As a convenient conversion, note that a salt flux of $1 \mathrm{mg}$ salt $\mathrm{m}^{-2} \mathrm{~s}^{-1}$ is equivalent to a daily sea ice production of $3 \mathrm{~mm}$ of ice (assuming water and ice salinities of 33.8 and 5.0, respectively) or daily precipitation of $2.5 \mathrm{~mm}$.

The vertically integrated temperature change over $150 \mathrm{~m}$ from summer to fall indicates net cooling in the southwest and net heating in the northeast (Figure 9a) with the dividing line occurring about midway along the shelf. Cooling is also larger in the midshelf to outer shelf and increases to the south. Part of this pattern of temperature change is due to the duration of the fall cruise (Table 1) and the fact that stations were occupied from north to south. Considerable cooling had already occurred by the time that the southern stations were occupied during the fall cruise.

Cooling occurs everywhere in the upper layer from fall to winter (Figure $9 \mathrm{~b}$ ). Along each across-shelf transect, cooling is weakest in the center of the shelf relative to that on either side. More cooling occurs in the northeast due to the latitudinal variation of summer warming and the fact that northern stations in the fall were taken before strong cooling occurred.

From winter to summer there is warming everywhere (Figure 9c) over the surface with net heating ranging from 20 to almost $100 \mathrm{~W} \mathrm{~m}^{-2}$. There is no defined spatial pattern, although the largest heating occurs in the inner 600 Line where WW has been eroded by summer heating and deep mixing (Figures 4 and 5).

The surface waters become fresher everywhere over this time (Figure 10a) except along the inner shelf in the southern part of the study area, at the shelf break along the transect at the 400 Line and in a limited area in the middle shelf along the 600 Line. The largest salinity decrease is along the inner shelf (X.060 to X.080) and to the southwest of the 350 Line.

The fall-to-winter salt change is everywhere positive except for one location (Figure 10b). The smallest salt change occurs in the center of the domain (along the $\mathbf{4 0 0}$
Line); the largest salt change occurs in the center of the shelf along each transect. Large salinity increases occur everywhere inside of the shelf break with values between 2.0 and $4.0 \mathrm{mg}$ salt $\mathrm{m}^{-2} \mathrm{~s}^{-1}$, which is equivalent to
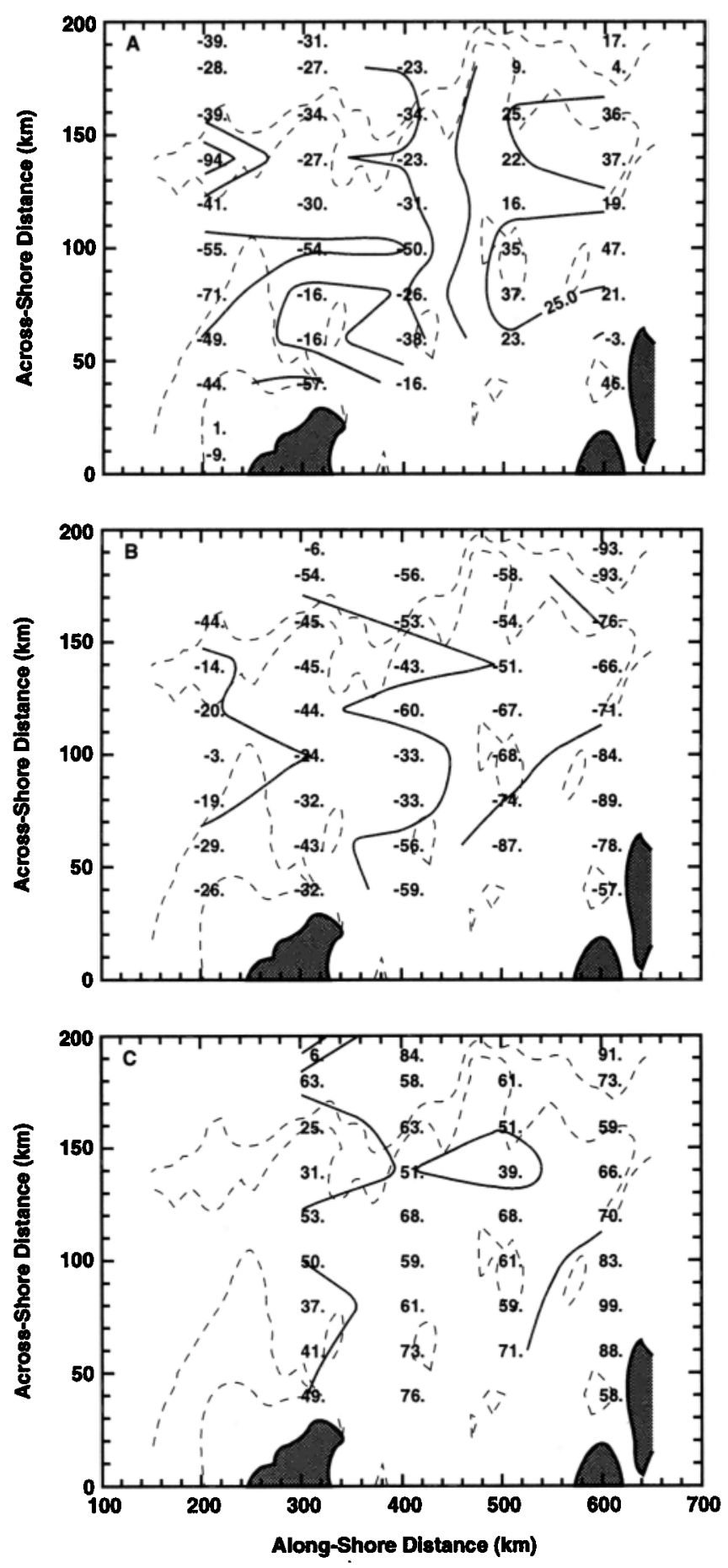

Figure 9. Heat change $\left(\mathrm{W} \mathrm{m}^{-2}\right)$ integrated over the upper $150 \mathrm{~m}$. The numbers on the figure are the integrated change. Solid lines are contours with an interval of 25. The dashed lines are the 500 and $1000 \mathrm{~m}$ isobaths. Shading indicates land. (a) Heat change between cruises 93a and 93b. (b) Heat change between cruises 93b and 93c. (c) Heat change between cruises 93c and 94a. 

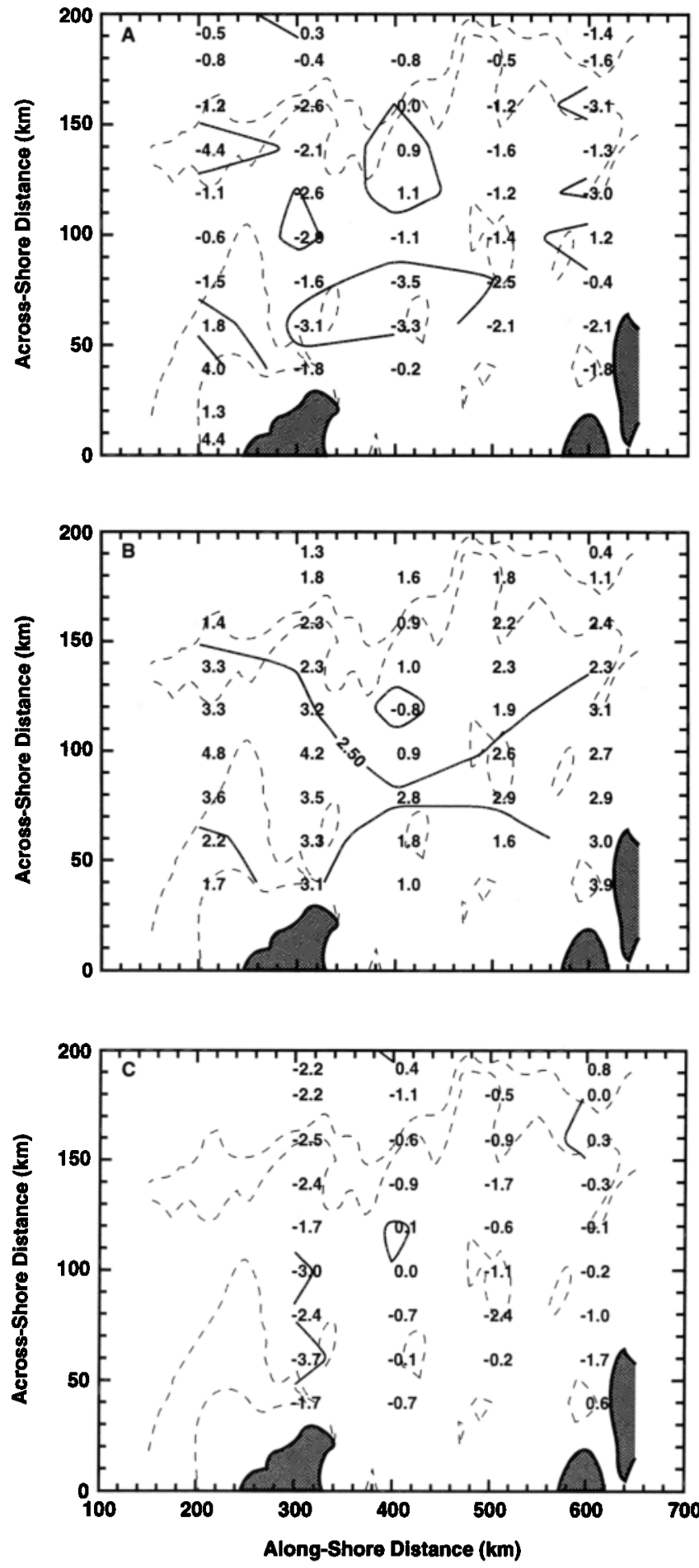

Figure 10. Salt change (mg salt $\left.\mathrm{m}^{-2} \mathrm{~s}^{-1}\right)$ integrated over the upper $150 \mathrm{~m}$. The numbers on the figure are the integrated change. Solid lines are contours with an interval of 2.5. The dashed lines are the 500 and $1000 \mathrm{~m}$ isobaths. Shading indicates land. (a) Salt change between cruises 93a and 93b. (b) Salt change between cruises $93 \mathrm{~b}$ and 93c. (c) Salt change between cruises 93c and 94a.

daily production of 6 to $12 \mathrm{~mm}$ of ice. From winter to summer the surface salinity decreases over most of the study region (Figure 10c), with the largest changes in the inner to middle southwestern shelf.
The integrated temperature and salt changes below the permanent pycnocline $(150$ to $500 \mathrm{~m})$ are more variable in space than the surface values and appear to be influenced by the bottom topography. The wide spacing of the hydrographic measurements and the small temperature contrast below $200 \mathrm{~m}$ results in fields that are not easy to contour. Therefore the values obtained for the vertical integrals of heat and salt change are shown overlaid on the bathymetry (Figures 11, 12).
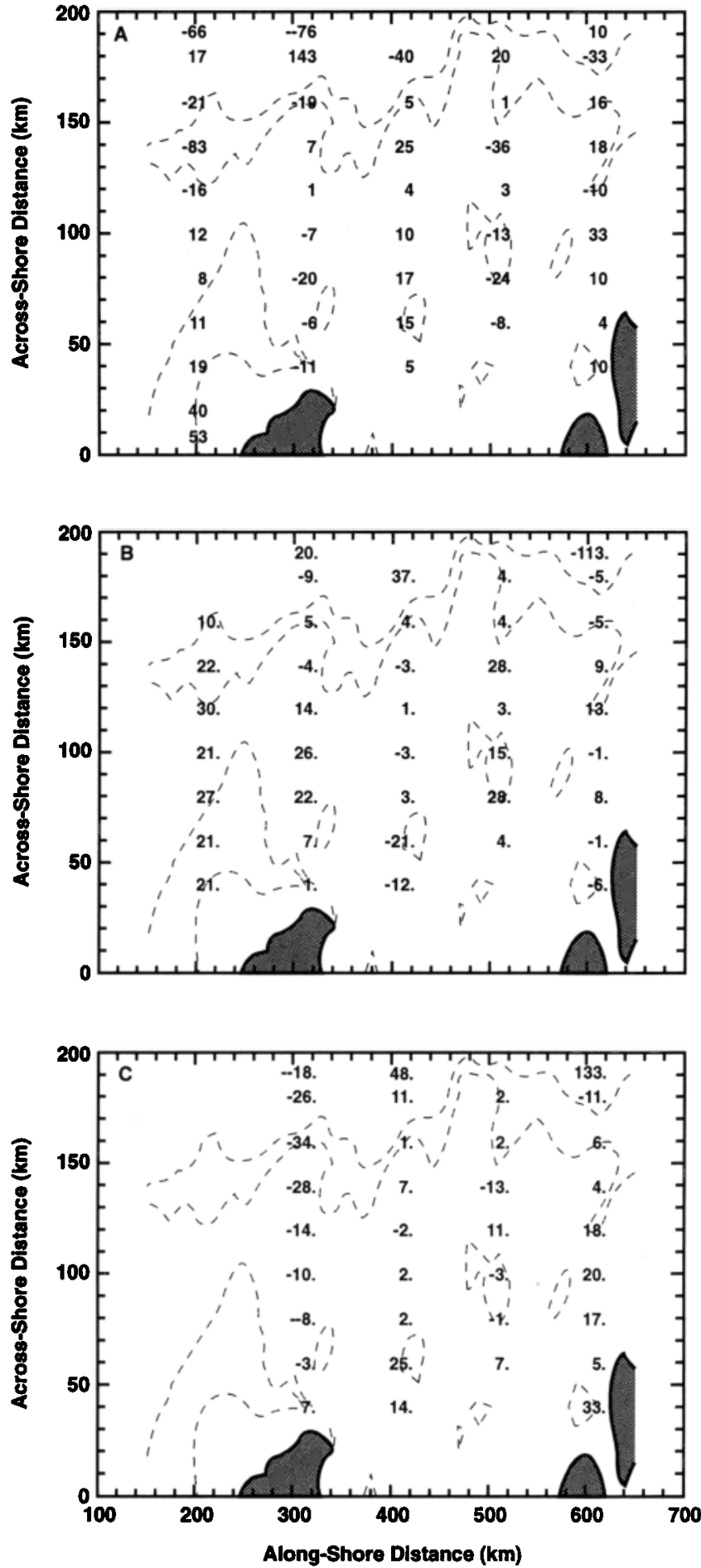

Figure 11. Same as Figure 9, except integrated from 150 to $500 \mathrm{~m}$ (or the bottom). 

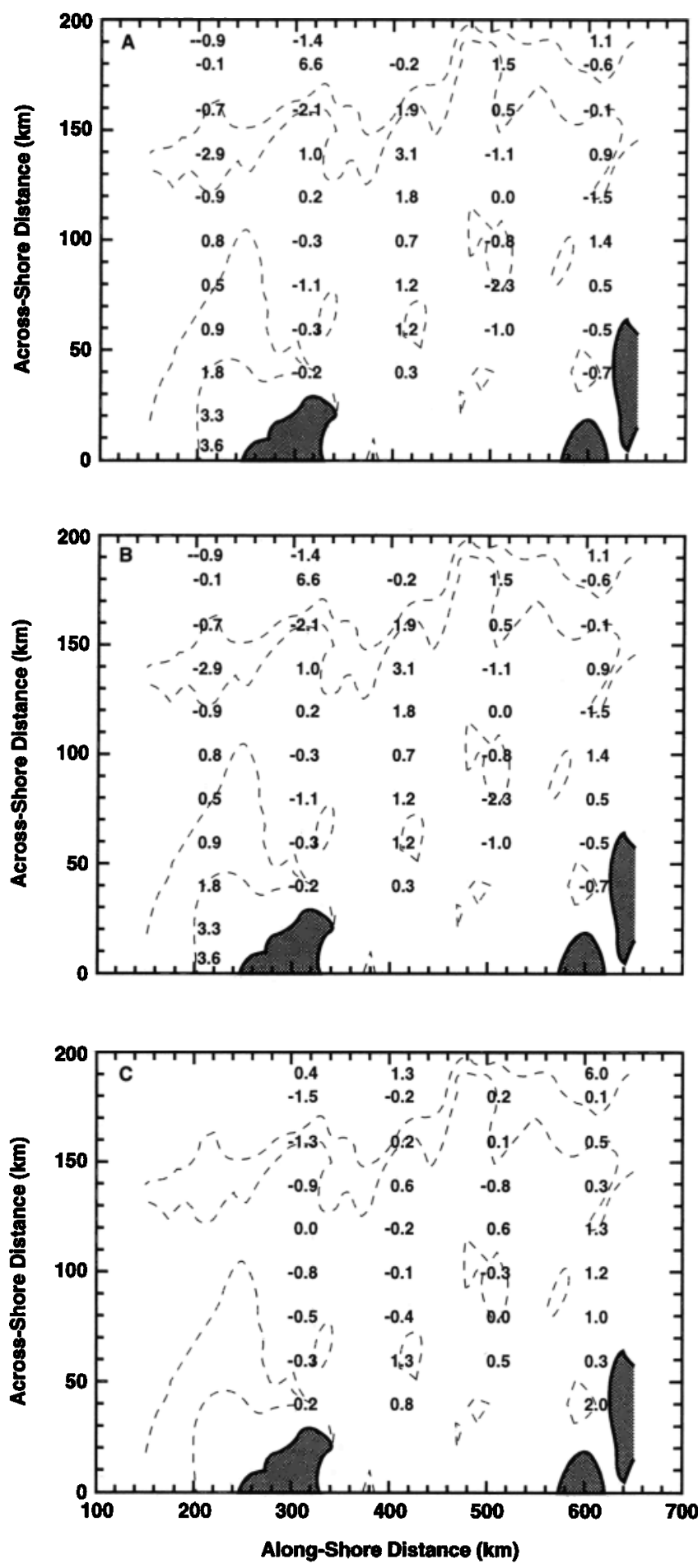

Figure 12. Same as Figure 10, except integrated from 150 to $500 \mathrm{~m}$ (or the bottom).

The summer to fall integrated temperature change below the pycnocline (Figure 11a) is smaller than the integrated surface change (Figure $9 \mathrm{a}$ ), and the sign of the change alternates between transects in the mid and inner shelf. The largest temperature changes are along the inner part of the 200 Line. Variations offshore of the $500 \mathrm{~m}$ isobath are due to meanders of the ACC as it interacts with the strong alongshore variation in the bottom topography [Klinck, 1997; Hofmann and Klinck, 1998].

The subpycnocline waters warm from fall to winter (Figure 11b) except along parts of the 400 and 600 Lines. Much of the cooling occurs near the shelf break due to ACC variability. The large cooling at the outer end of the 600 Line is due to an unusually thick surface mixed layer during the winter cruise which was formed by strong cooling and wind forcing and no ice cover. Strong and consistent warming occurs along the 200 Line and in the middle part of the 300 Line due to movement of UCDW into this region [Hofmann and Klinck, 1998]. At both locations, the volume of water with temperatures above $1.2^{\circ} \mathrm{C}$ increases from fall to winter.

The temperature change in the subpycnocline waters between winter and summer differ in the northern and southern parts of the study region (Figure 11c). To the southwest, cooling of -10 to $-35 \mathrm{~W} \mathrm{~m}^{-2}$ occurs; to the northeast, there is warming ranging from 0 to 30 $\mathrm{W} \mathrm{m}^{-2}$. However, the changes in the northeast have more spatial variability than those to the south.

The integrated summer-to-fall salt change has a spatial pattern (Figure 12a) similar to that of temperature change; the inner and outer shelves act differently, and the sign of the change alternates between across-shelf transects with temperature and salinity simultaneously increasing or decreasing. The salinity changes at the shelf break on the 300,400 , and 600 Lines have different signs indicating shifts of the ACC. Warming and salting occurs over the shallow areas of the shelf and cooling and freshening over deeper areas, but this trend does not always hold.

The fall-to-winter subpycnocline salinity changes are positive everywhere except along the inner and outer parts of the 400 Line (Figure 12b). The integrated changes are largest in the southwest and decrease toward the northeast. The variability in the salt flux at the outer ends of the 200,400 , and 600 Lines indicates position changes of the ACC.

From winter to summer the subpycnocline waters freshen over the southwestern part of the study region and in the midshelf (Figure 12c). Salinity increases along the inner shelf and along the 600 Line. The largest changes occur along the 200 and 600 Lines, but with opposite signs.

\subsection{Changes From Summer 1993 to Summer 1994}

The assumption underlying the above results is that the seasonal change in the heat and salt content is larger than the interannual changes. Given the high latitude, it seems reasonable that the extreme seasonal changes in the atmosphere produce large seasonal changes in the water. However, surface fluxes can vary from year to year. An indication of the size of interannual variation in water properties is obtained by comparing the austral summer water characteristics from 1993 with those of 
1994. This certainly is not a definitive statement of the possible variations, but it will support the assumption that near the surface the largest changes are primarily seasonal.

The temperature change between 1993 and 1994 along the $600,500,400$ and 300 Lines are everywhere less than $0.25 \mathrm{~W} \mathrm{~m}^{-3}$, and in most places, the changes are less than one fifth of this value (figures not shown). The largest changes occur in three places: above $80 \mathrm{~m}$, near the shelf break, and over the shelf below $100 \mathrm{~m}$. The surface mixed layer was somewhat colder in 1994 than in 1993 everywhere except along the 600 Line. The subpycnocline water in 1994 over the shelf was everywhere warmer than in 1993 except along the 300 Line where only the inner shelf was warmer. The salinity changes follow much the same spatial pattern as the temperature changes, with the largest salt changes being less than $20 \mu \mathrm{g}$ salt $\mathrm{m}^{-3} \mathrm{~s}^{-1}$, and most changes being less than a quarter of this value. For all four across-shelf transects, the mixed layer was somewhat fresher in 1994, and the subpycnocline waters were slightly more salty.
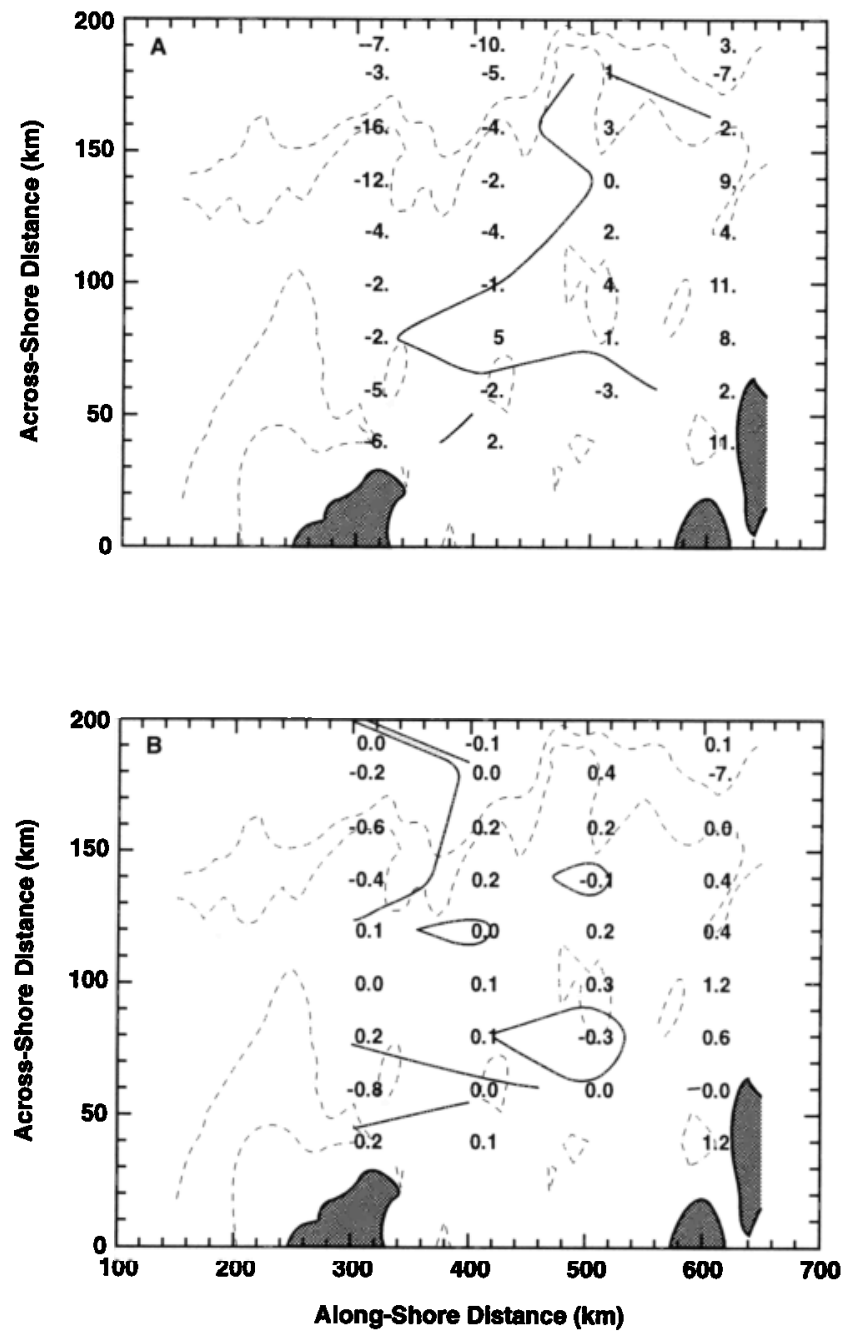

Figure 13. Heat and salt changes between January 1993 and January 1994 integrated over the upper 150 m. (a) Same as Figure 9. (b) Same as Figure 10.
The 300 Line departs from this subpycnocline pattern with saltier conditions on the inner and middle shelf and fresher conditions along the outer shelf.

The change in the vertically integrated surface heat content between the two years (Figure 13a) is 10 to 50 times smaller than any of the individual seasonal changes (Figure 9). In 1994 the southern portion of the study region was cooler than in 1993 and the northern portion is warmer, though the stations were occupied at nearly the same day 1 year apart. There is a weak trend of larger changes at the ends of the domain (300 and 600 Lines). All of these variations could be due to a small shift in timing of surface heating. The integrated abovepycnocline salinity changes (Figure 13b) are a factor of 2 to 10 smaller than the seasonal changes. The surface layer is saltier in 1994 with some isolated fresher areas at the shelf break on the 300 Line and in a band along the inner shelf. As with temperature, the largest salinity increase in the surface waters occurs along the 600 Line.

There is a slight increase in the subpycnocline temperatures in summer 1994, except near the shelf break at the outer 300 and 600 Lines (Figure 14a), although all of the integrated changes are about one fifth or less of the comparable seasonal changes. The largest changes over the shelf occur along the middle and inner part of the 600 line, and these integrated changes are comparable in size to those produced by the ACC meanders at the shelf break. The integrated subpycnocline salinity change (Figure 14b) is 2 to 5 times smaller than the seasonal changes. Between the two years, the deep waters became saltier everywhere except at the shelf break along the 300 and 600 Lines. The largest increases occur along the 600 Line and throughout the middle shelf portion of the study region.

\section{Discussion}

\subsection{Seasonal Changes}

Heat and salt changes above the permanent pycnocline are consistent with seasonally varying surface fluxes: surface waters warm over the spring and summer and cool in the fall and winter. Cooling to the depth of the permanent pycnocline (100-150 m) occurs in the fall and winter as the winds increase in strength and the seasonal pycnocline breaks down. Surface waters become fresher from winter to summer due to ice melt and saltier in the transition through fall to winter due to ice freezing. There is some indication that the mixed layer deepens in spring due to increased mixing driven by stronger surface winds and removal of the sea ice cover.

This seasonal cycle in the upper ocean is evident from simultaneous changes of temperature and salinity integrated over the top $150 \mathrm{~m}$ of the water column (Figure 15a). From winter to summer (symbol w) the water becomes warmer and fresher, due to surface heating and ice melting. From summer to fall (symbol s) the surface water either warms or cools and continues to freshen. 

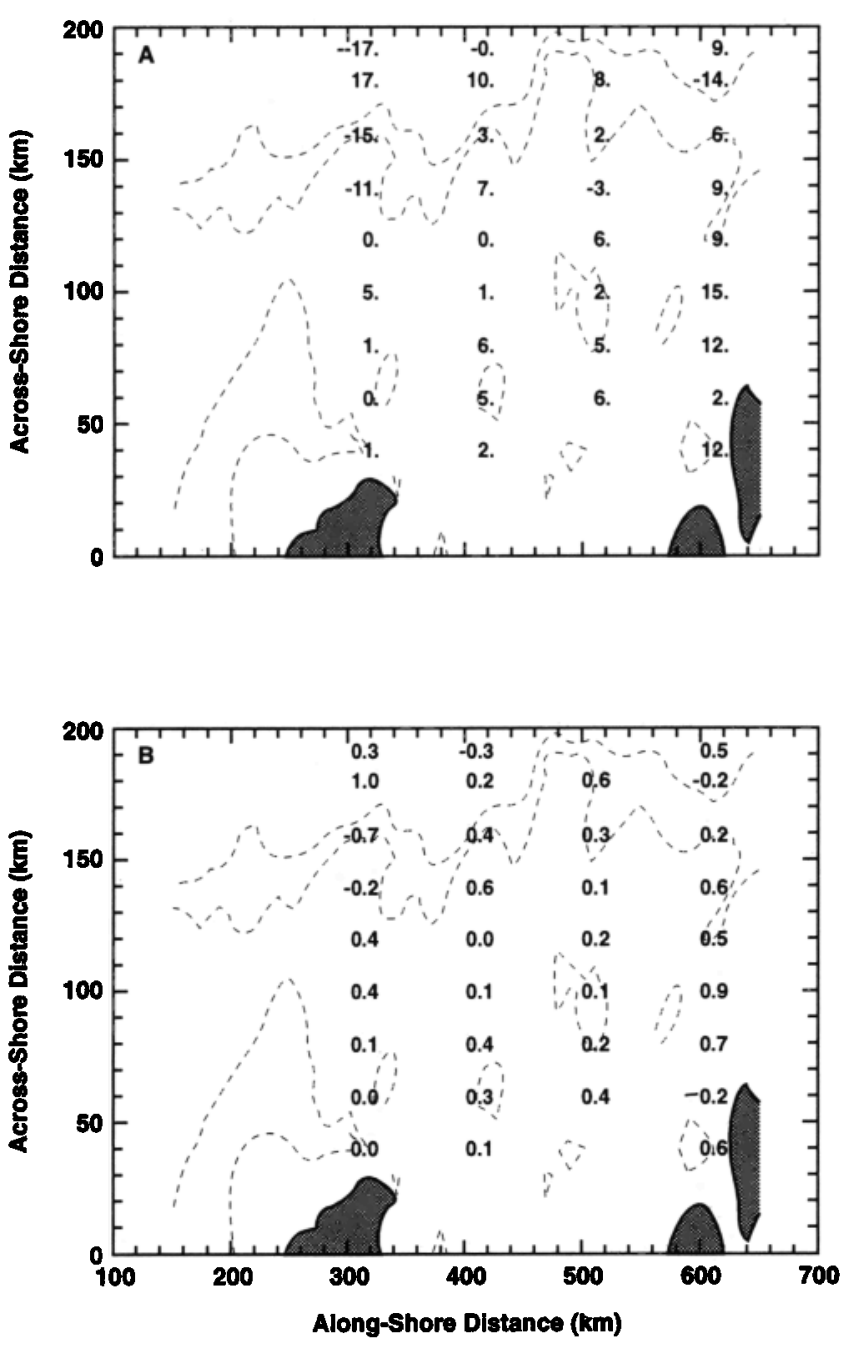

Figure 14. Heat and salt changes between January 1993 and January 1994 integrated from 150 to $500 \mathrm{~m}$ (or the bottom). (a) Same as Figure 9. (b) Same as Figure 10.

Because of the extended duration of the fall cruise, some stations were occupied in late summer (thus continuing to warm) while others were occupied after the surface waters had cooled. In the transition from fall to winter (symbol f), all stations had decreasing temperature and increasing salinity, consistent with surface cooling and freezing. Gordon [1981] estimates zonally averaged winter cooling rates of 79 to $95 \mathrm{~W} \mathrm{~m}^{-2}$ for the latitude band $60^{\circ}$ to $70^{\circ} \mathrm{S}$. Measurements from the Weddell Sea [Gordon and Huber, 1990, Figure 12] estimated a winter heat flux to the atmosphere of $41 \mathrm{~W} \mathrm{~m}^{-2}$ which is consistent with values in this study.

Changes below the permanent pycnocline do not follow a seasonal pattern. In the northeastern end of the study region, deep water warms throughout the year; a pattern that can not continue indefinitely. Furthermore, deep water warms in winter over the whole domain and cools in summer over the southern half of the domain, changes which are opposite to those expected from sur- face fluxes. Salinity changes below the pycnocline are a mixture of salting and freshening from summer to fall, but an increase in salinity everywhere from fall to winter (Figure 12). The deep water becomes fresher in the transition from winter to summer, which could be associated with the seasonal cycle of ice freezing and melting, except that the spatial patterns of salt and temperature changes appear to be correlated.

The pattern of changes in subpycnocline water (Figure $15 \mathrm{~b}$ ) is clearly different from that observed near the surface (Figure 15a), with magnitudes about half those in the mixed layer. Regardless of season, water becomes warmer and saltier or cooler and fresher, changes that can not be produced by surface fluxes. These changes occur by exchanges of UCDW and WAP Shelf Water. If UCDW replaces WAP Shelf Water, both temperature and salinity increase; both decrease if WAP Shelf Water replaces UCDW. If LCDW replaces UCDW, the change is towards colder and saltier, similar to that produced by surface fluxes. If LCDW replaces WAP Shelf Water, the change is towards warmer and saltier. Based on the integrated subpycnocline changes, exchange of WAP. Shelf Water and UCDW is the mechanism by which the characteristics of the subpycnocline waters change and this process is not related to season.

Observed patterns of change can be compared to those expected from the proposed water exchange. From the cruise data, UCDW is observed to be $1.9^{\circ} \mathrm{C}$ and 34.66 while WAP Shelf Water is $1.3^{\circ} \mathrm{C}$ and 34.69. If there were a pure exchange of UCDW and WAP Shelf Water, then the ratio of heat to salt change would be $120 \mathrm{~J} \mathrm{mg} \mathrm{salt}^{-1}\left(=c_{p} \Delta T / \Delta S\right)$ (dashed line on Figures $15 \mathrm{~b}$ and $15 \mathrm{c}$ ). A least squares fit to all of the measured changes (solid line on Figures $15 \mathrm{~b}$ and $15 \mathrm{c}$ ) is $20.6 \mathrm{~J}$ $\mathrm{mg}$ salt $^{-1}$; the observed temperature change is smaller for a given salinity change than would be true for pure exchange of UCDW and WAP shelf water. UCDW must lose heat or gain salt in the process of flooding the shelf. Heat can be lost to the WW layer during the exchange (a plausible downgradient diffusion of heat). The surface layer is fresher than either UCDW or WAP Shelf Water, so there is no salt source to increase the salinity of UCDW. The exchange of water across the shelf break therefore must involve a messy mixing of the two water masses with exchange of heat across the pycnocline; there is no simple advective replacement of one water mass with another.

\subsection{Interannual Changes}

The change between the summers of 1993 and 1994 provides the first estimate of interannual variability of the west Antarctic Peninsula continental shelf waters. In January 1994 the southwestern continental shelf surface waters are cooler and the northeastern shelf waters are warmer than January 1993 (Figure 13a), even though the hydrographic measurements in the two years were taken at almost the same year-day. The observed 

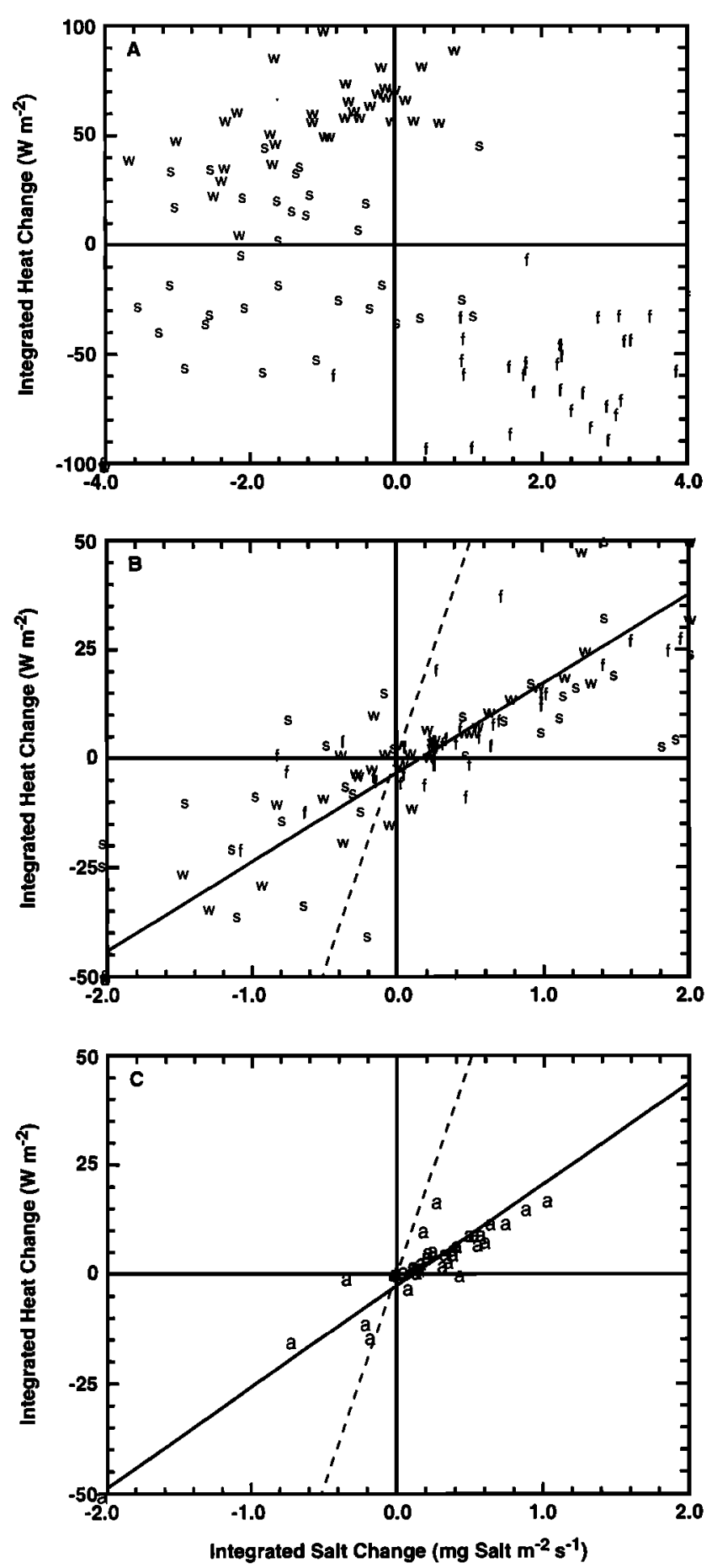

Figure 15. Vertically integrated salt and heat change between successive cruises using the interpolated values. Each symbol represents a station that was repeated. The change from cruise $93 \mathrm{a}$ to $93 \mathrm{~b}$ is indicated by $\mathrm{s}$, from cruise $93 \mathrm{~b}$ to $93 \mathrm{c}$ by $\mathrm{f}$, from cruise $93 \mathrm{c}$ to $94 \mathrm{a}$ by $\mathrm{w}$, and from cruise 93a to 94a by a. A few values are outside the range of the plot and are shown by symbols just outside the plot boundary. (a) Near surface changes (integrated to $150 \mathrm{~m}$ ). (b) Subpycnocline seasonal changes (integrated from 150 to $500 \mathrm{~m}$ ). The solid line is a linear fit to the points. The dashed line is the expected change if pure UCDW replaces pure WAP Shelf Water. (c) Subpycnocline annual changes (integrated from 150 to $500 \mathrm{~m}$ ). The solid line is a linear fit to the points. The dashed line is the expected change if pure UCDW replaces pure WAP Shelf Water. interannual variability may simply result from the difference in the time of summer warming in the two years. However, saltier surface waters in 1994 (Figure 13b) can not be explained by timing. This difference represents a smaller net ice melt in late 1993 or a greater freezing in mid-1993 as compared to the previous year. It could also indicate less import of ice from the southwest or more export of ice to the northeast during the winter of 1993 . The sea ice extent in winter 1993 was larger than 1992 [Stammerjohn and Smith, 1996] which may account for the increased salt in summer 1994 .

Summer-to-summer changes are smaller than seasonal changes, but the implications are different above and below the permanent pycnocline. The surface waters are strongly affected by surface fluxes, and seasonal changes are expected to be larger than changes between successive years; the surface water characteristics should approximately repeat from year to year. The centroid of interannual near-surface changes (figure not shown) reveals slight cooling and salting, but the difference from zero is small compared to the changes between seasons.

Water mass changes below the pycnocline have considerable variability (Figure 15b) but no seasonal pattern, indicating a weak connection between the surface fluxes and the deeper water. Changes in the subpycnocline waters between summer 1993 and 1994 (Figure 15c) follow the same trend as the seasonal changes but with about one-half the magnitude. This reduction may be due to erosion over the year of the signal created by exchanges of different types of waters; that is, the yearto-year differences integrate the variability that occurs on faster than annual timescales.

Subpycnocline waters have a definite and simple variation between the two summers: the water at almost every station is warmer and saltier in 1994 compared to 1993 (Figure 15c). During the 1993 calendar year, UCDW advected or mixed onto the west Antarctic Peninsula continental shelf replacing WAP Shelf Water, which either moved alongshore or crossed the shelf break. The mechanism by which this exchange occurs is not clear; nor is it clear if this change during 1993 is large or small compared to other years.

\subsection{Rates of Heat and Salt Flux}

The following simple model is proposed to analyze the flux of the heat and salt through the sub-pycnocline layer. This model assumes no net exchange of heat or salt in the alongshore direction, which is reasonable as the hydrographic conditions do not change in any substantial way along this shelf [Hofmann and Klinck, 1997]. This assumption ignores potentially important processes associated with sea ice, such as the import of sea ice over winter which melts in the summer. Exchanges across the shelf edge are assumed to be purely diffusive since no evidence exists for a persistent current. Based on dynamic calculations, Smith et al. [1998] 
find a weak cyclonic gyre over this shelf with baroclinic flow of order 0.01 to $0.02 \mathrm{~m} \mathrm{~s}^{-1}$ at $200 \mathrm{~m}$ relative to $400 \mathrm{~m}$, with no indication of flow across the shelf break. Because of the gyre structure of the flow on this shelf, there does not seem to be a net advection across the shelf break.

Thus model processes are chosen to be across-shore diffusion at the shelf break and upward diffusion through the permanent pycnocline into the surface layer. Vertical diffusion represents entrainment, double diffusion, internal wave breaking and all other processes of vertical exchange across the pycnocline. Horizontal diffusion represents small-scale turbulence and intrusive layering as well as mesoscale instabilities (meanders and eddies) at the shelf break. The surface layers exchange heat with the atmosphere and salt with sea ice. Thus it is not necessary to consider the exchanges in the surface layer, except to note that the cross-pycnocline fluxes are smaller than estimated air-sea exchanges. Furthermore, every winter the surface layer cools to the freezing point thus stripping all of the heat that accumulated over the year. Salt is restored to the surface layer through ice creation. Each winter, the mixed layer returns to the same condition.

The model equations are obtained from a volume integral of the equations governing diffusion of heat and salt over the subpycnocline waters of the shelf with the assumption that there are no gradients alongshore and that the coast and the bottom allow no flux of heat or salt.

$$
\begin{aligned}
& \left.\frac{h}{L} A_{h} \frac{\partial T}{\partial x}\right|_{b}-\left.A_{v t} \frac{\partial T}{\partial z}\right|_{p}=\frac{1}{\rho_{o} c_{p} L} I_{H} \\
& \left.\frac{h}{L} A_{h} \frac{\partial S}{\partial x}\right|_{b}-\left.A_{v s} \frac{\partial S}{\partial z}\right|_{p}=\frac{1}{\rho_{o} L} I_{S},
\end{aligned}
$$

where $x$ and $z$ are positive offshore and upward, subscripts $b$ and $p$ indicate gradients at the shelf break and pycnocline, and $I_{H}$ and $I_{S}$ are the volume integrated heat and salt change below the pycnocline, respectively. Vertical diffusivities of heat and salt, $A_{v t}$ and $A_{v s}$, may differ but horizontal diffusivity $A_{h}$ is the same for both. The remaining parameters in the model represent the thickness of the subpycnocline waters $(h=350 \mathrm{~m})$, the across-shelf distance $(L=150 \mathrm{~km})$, the specific heat of seawater $\left(c_{p}=3987 \mathrm{~J} \mathrm{~kg}^{-1}{ }^{\circ} \mathrm{C}^{-1}\right)$, and the water density $\left(\rho_{o}=1028 \mathrm{~kg} \mathrm{~m}^{-3}\right)$.

All of the model parameters can be estimated from the hydrographic observations, except the diffusion coefficients. Temperature and salinity were averaged over the top $100 \mathrm{~m}$ and over 200 to $500 \mathrm{~m}$ for each of the cruises. Vertical differences of these spatial averages give $1.25^{\circ} \mathrm{C}$ and 1.0 , for temperature and salinity, respectively, over $350 \mathrm{~m}$ (distance between the centers of each of the averaging layers). Horizontal differences at the shelf break (over about $50 \mathrm{~km}$ ) were $0.6^{\circ} \mathrm{C}$ and 0.2 , for temperature and salinity, respectively (see Figures 4 and 5). These differences change little over the year and thus represent annual mean conditions. For these values, the above heat and salt budget equations reduce to

$$
\begin{aligned}
& A_{h}-1.27 \times 10^{5} A_{v t}=24.67 \\
& A_{h}-3.06 \times 10^{5} A_{v s}=26.28
\end{aligned}
$$

These equations are underdetermined and are solved using singular value decomposition [Press et al., 1986, p. 52ff]. The singular value solution is $(0.178,-1.933$, $-0.854)$ for $\left(A_{h}, 10^{4} \times A_{v t}, 10^{4} \times A_{v s}\right)$ with a null vector of $(0.9964,0.07826,0.03215)$. With no contribution from the null space, both of the vertical diffusivities are negative, which is thermodynamically invalid. Positive definite diffusivities are obtained by adding a contribution from the null space vector so that the largest vertical diffusivity is $10^{-4} \mathrm{~m}^{2} \mathrm{~s}^{-1}$. The resulting solution is $(37.43,1.00,0.364)$. Other solutions are possible (which the reader is invited to investigate), but the relative magnitudes do not change for other plausible choices. Note that the vertical diffusivity for heat is about 3 times that for salt, which is consistent with other studies [Martinson, 1990].

Based on these diffusivities, it is possible to calculate the heat flux across the pycnocline of $1.46 \mathrm{~W} \mathrm{~m}^{-2}$ and an onshore heat flux of $1839 \mathrm{~W} \mathrm{~m}^{-2}$. The resulting vertical and horizontal salt fluxes are $0.107 \mathrm{mg}$ salt $\mathrm{m}^{-2} \mathrm{~s}^{-1}$ and $154 \mathrm{mg}$ salt $\mathrm{m}^{-2} \mathrm{~s}^{-1}$, respectively. The horizontal fluxes can be compared to the vertical fluxes by multiplying by the aspect ratio of the shelf $(H / L)$ which results in equivalent vertical fluxes of 4.29 $\mathrm{W} \mathrm{m} \mathrm{m}^{-2}$ and $0.36 \mathrm{mg}$ salt $\mathrm{m}^{-2} \mathrm{~s}^{-1}$. The large onshore flux relative to the vertical flux is consistent with the observed deep warming and salt increase between January 1993 and January 1994. These fluxes are small compared to the surface heat and salt flux, but they operate throughout the year.

It is possible to construct a plausible budget to explain the observed annual heat and salt changes over the west Antarctic Peninsula continental shelf using only across-shelf and vertical turbulent diffusive exchanges. It is worth noting that the total flux of heat and salt across this shelf is larger than is required to explain the interannual difference. In other words, the net changes are produced by differences between subpycnocline onshore and vertical fluxes through the pycnocline. Other budgets and more comprehensive models which are beyond the scope of this paper are being investigated.

\subsection{Other Changes}

4.4.1. Wind effects. Calculations presented in section 2 show that Ekman transports are weak and are not capable of producing substantial motion of water in the mixed layer. The important effect of wind stress seems to be deep mixing that gives rise to a thicker layer of cold water than can be warmed during the summer.

4.4.2. Changes at the shelf break. The southern edge of the ACC, indicated by the position of the $1.8^{\circ} \mathrm{C}$ isotherm at about $300 \mathrm{~m}$ [Orsi et al., 1995], is 
along the continental shelf break of the Antarctic Peninsula. The location of this isotherm for each of the sampling lines for each cruise (Table 4) shows that the position of the ACC relative to the shelf break is variable. The ACC edge is relatively stable only at the 200 Line; it is always offshore at the $\mathbf{3 0 0}$ and $\mathbf{4 0 0}$ Lines. At the 500 Line it was observed only once at the shelf break. The timing and duration of shifts in the location of the ACC are presently unknown, although given the meander cycle of other fast boundary currents, such as the Gulf Stream, the shift in the location of this current can occur in as little time as a week [e.g., Lee and Atkinson, 1983].

4.4.3. Topographic effects. The bottom topography of the west Antarctic Peninsula continental shelf is rugged with minimum depths of $200 \mathrm{~m}$ and depressions deeper than $800 \mathrm{~m}$ (Figure 1). Some of these deeper areas extend from the shelf break to the middle or inner shelf. One prominent channel is northwest of Anvers Island and extends most of the way across the shelf. A second deep area on the shelf is west of Adelaide island. These across-shelf channels provide conduits for water from the ACC (UCDW) to move into the inner parts of the shelf [Smith et al., 1998; Hofmann and Klinck, 1998]. As evidence for this, consider the temperature and salinity changes displayed in Figures 11 and 12 and notice that there is almost always a different change over the deeper areas of the shelf. This difference is particularly clear along the middle part of the 600 Line (at 600.140). The influence of bottom topography on across-shelf transport is clear from the temperature at the subpycnocline temperature maximum (figure not shown), in which plumes of warm water align with the axes of these across-shelf channels [Hofmann and Klinck, 1998].

\section{Summary}

The hydrographic measurements from four cruises over the continental shelf west of the Antarctic Penin-

Table 4. Location of the $1.8^{\circ} \mathrm{C}$ Isotherm at a depth of 300 to $400 \mathrm{~m}$ for Each Cruise and Each Across-Shelf Transect

\begin{tabular}{lccccc}
\hline & \multicolumn{5}{c}{ Cruise } \\
\cline { 2 - 5 } Distance, km & $\mathbf{9 3 a}$ & $93 \mathbf{b}$ & $93 \mathbf{c}$ & $\mathbf{9 4 a}$ & Shelf Break \\
\hline 200 & 150 & 150 & 160 & $\ldots$ & 140 \\
300 & + & 160 & 180 & 185 & 160 \\
400 & 180 & + & + & 180 & 160 \\
500 & + & + & + & + & 190 \\
600 & 190 & 190 & + & 195 & 170 \\
& & & & & \\
\hline
\end{tabular}

The location is given in kilometers from the baseline defined by the LTER coordinate system. A plus indicates the that the isotherm was farther offshore than sampling extended. The shelf break is taken to be the $750 \mathrm{~m}$ isobath. sula between January 1993 and January 1994 afford a unique opportunity to analyze the changes in temperature and salinity in a high-latitude system that reacts to strong atmospheric forcing. The high density of observations allows analysis of water temperature and salinity changes between the cruises, as well as for the same month (January) in consecutive years.

The first result of this study is that the measured changes in heat and salt content are larger than those expected from sensor precision and internal wave activity. Furthermore, the spatial patterns of these changes are consistent between adjacent sampling locations. Water property changes are different on either side of the permanent pycnocline $(150 \mathrm{~m})$ which is produced each winter by surface cooling and deep wind mixing.

Water property changes above the permanent pycnocline follow the expected seasonal pattern of cooling and increasing in salt from summer to winter and warming and freshening from winter to summer. The integrated heat change is above $80 \mathrm{~W} \mathrm{~m}^{-2}$, while the salt change is above $4 \mathrm{mg}$ salt $\mathrm{m}^{-2} \mathrm{~s}^{-1}$. From January 1993 to January 1994 , the changes above the permanent pycnocline were smaller than those between seasons. Surface waters in January 1994 are cooler and saltier than in January 1993.

There was no seasonal cycle below the permanent pycnocline; rather, both heat and salt content either increase or decrease. The observed differences can not be created by surface fluxes but rather are created by the exchange of UCDW across the shelf break replacing WAP Shelf Water. The magnitudes of the heat and salt flux below the permanent pycnocline $\left(50 \mathrm{~W} \mathrm{~m}^{-2}\right.$ and $2.0 \mathrm{mg}$ salt $\mathrm{m}^{-2} \mathrm{~s}^{-1}$ ) are about half of that observed near the surface. The changes over 1 year are more consistent spatially below the permanent pycnocline with annual warming $\left(10 \mathrm{~W} \mathrm{~m}^{-2}\right)$ and increase in salt $(0.5$ mg salt $\left.\mathrm{m}^{-2} \mathrm{~s}^{-1}\right)$. This increase in salt can be balanced by $1.25 \mathrm{~mm} / \mathrm{d}(0.46 \mathrm{~m} / \mathrm{yr})$ precipitation which is within a factor of 2 of the observed precipitation at Palmer station (0.4 to $1.0 \mathrm{~m} / \mathrm{yr}$ [Antarctic Journal of the United States, 1991, 1992, 1993]).

A simple model is used which balances across-shelf diffusion of heat and salt from the ACC and vertical diffusion of heat and salt to the cold fresh Winter Water just above the pycnocline. The net annual change in the heat and salt content of the bulk of the shelf is easily obtained as a difference in the onshore and vertical fluxes with vertical diffusivities of heat and salt of $1.0 \times 10^{-4}$ and $0.36 \times 10^{-4} \mathrm{~m}^{2} \mathrm{~s}^{-1}$ and horizontal diffusivity of about $37 \mathrm{~m}^{2} \mathrm{~s}^{-1}$.

The changes of heat and salt in the subpycnocline waters are consistent with a net flux of UCDW onto the west Antarctic Peninsula shelf during this year replacing WAP Shelf Water which either moves alongshore outside of the sampling region or across the shelf break. This exchange likely occurred between the 1993 fall and winter cruises. Hydrographic changes between 
other cruises show increases of heat and salt, but over limited parts of the continental shelf. The mechanisms by which the onshore movement of UCDW occurs is not known. I speculate that meanders of the ACC cause this exchange. I also speculate that deep across-shelf channels in the bottom topography facilitates this exchange.

Acknowledgments. This work was supported by the U.S. National Science Foundation by grant DPP-90-11927. Computer facilites and support were provided by the Commonwealth Center for Coastal Physical Oceanography.

\section{References}

Antarctic Journal of the United States, Weather at U.S. stations, 26(4),23, 1991.

Antarctic Journal of the United States, Weather at U.S. stations, 27(4),23, 1992.

Antarctic Journal of the United States, Weather at U.S. stations, 28(4),23, 1993.

Darby, M. S., A. J. Willmott, and T. A. Somerville, On the influence of coastline orientation on the steady state width of a latent heat polynya, J. Geophys. Res., 100, 13,625$13,633,1995$.

Foster, T. D., and E. C. Carmack, Frontal zone mixing and Antarctic Bottom Water formation in the southern Weddell Sea, Deep Sea Res., 23, 301-317, 1976.

Gordon, A. L., Seasonality of Southern Ocean sea ice, $J$. Geophys. Res., 86, 4193-4197, 1981.

Gordon, A. L., and B. A. Huber, Southern Ocean winter mixed layer, J. Geophys. Res., 95, 11,655-11,672, 1990.

Grumbine, R. W., A model of the formation of high-salinity shelf water on polar continental shelves, J. Geophys. Res., 96, 22,049-22,062, 1991.

Hofmann, E. E., and J. M. Klinck, Antarctic continental shelf oceanography, in The Sea, vol. 11, edited by A. R. Robinson and K. H. Brink, John Wiley, New York, in press, 1997.

Hofmann, E. E., and J. M. Klinck, Seasonal variation of the hydrography and circulation of the west Antarctic Peninsula continental shelf, in Antarctıc Continental Shelf Oceanography, Antarct. Res. Ser., edited by S. S. Jacobs and R. Weiss, AGU, Washington, D. C., in press, 1998.

Hofmann, E. E., J. M. Klinck, C. M. Lascara, and D. A. Smith, Water mass distribution and circulation west of the Antarctic peninsula and including Bransfield Strait, in Foundations for Ecological Research West of the Antarctic Peninsula, Antarct. Res. Ser., vol. 70, edited by R. M. Ross et al., pp. 61-80, AGU, Washington, D. C., 1996.

Jacobs, S. S., A. F. Amos, and P. M. Bruchhausen, Ross Sea oceanography and Antarctic Bottom Water formation, Deep Sea Res., 17, 935-962, 1970.

Katsaros, K., and S. Pouliquen, Scatterometer mean wind field products, 57 pp., Tech. Rep. C2-MUT-W-02-IF, Inst. Fr. de Rech. pour l'Exploit. de la Mer, Plouzane, France, 1996.

Klinck, J. M., Palmer LTER: Temporal variability in the location of the ACC along the west Antarctic Peninsula continental shelf, Antarc. J. U. S., in press, 1997

Klinck, J. M. and R. C. Smith, Hydrographic data collected aboard RV Polar Duke, August-September 1993, 152 pp., CCPO Tech. Rep. 94-01, Old Dominion Univ., Norfolk, Va., 1994.

Lascara, C. M., R. C. Smith, D. Menzies, and K. S. Baker, Hydrographic data collected aboard RV Polar Duke, No- vember 1991, 307 pp., CCPO Tech. Rep. 93-01, Old Dominion Univ., Norfolk, Va., 1993a.

Lascara, C. M., R. C. Smith, D. Menzies, and K. S. Baker, Hydrographic data collected aboard RV Polar Duke, January-February 1993, 95 pp., CCPO Tech. Rep. No. 93-02, Old Dominion Univ., Norfolk, Va., 1993b.

Lee, T. N., and L. P. Atkinson, Low-frequency current and temperature variability from Gulf Stream frontal eddies and atmospheric forcing along the southeast U.S. outer continental shelf, J. Geophys. Res., 88, 4551-4567, 1983.

Lemke, P., W. B. Owens, and W. D. Hibler III, A coupled sea ice-mixed layer-pycnocline model for the Weddell Sea, J. Geophys. Res., 95, 9513-9525, 1990.

Martinson, D. G., Evolution of the Southern Ocean winter mixed layer and sea ice: Open ocean deepwater formation and ventilation, J. Geophys. Res., 95, 11,641-11,654, 1990.

Orsi, A. H., R. Whitworth III, and W. D. Nowlin Jr., On the meridional extend and fronts of the Antarctic Circumpolar Current, Deep Sea Res., 5, 641-673, 1995.

Ou, H. W., A time dependent model of a coastal polynya, J. Phys. Oceanogr., 18, 584-590, 1988.

Owens, W. B., and P. Lemke, Sensitivity studies with a sea ice-mixed layer-pycnocline model in the Weddell Sea, $J$. Geophys. Res., 95, 9527-9538, 1990.

Pease, C. H., The size of wind-driven coastal polynyas, $J$. Geophys. Res., 92, 7049-7059, 1987.

Press, W. H., B. P. Flannery, S. A. Teukolsky, and W. T. Vettering, Numerical Recipes: The Art of Scientific Computing, 818 pp., Cambridge Univ. Press, New York, 1986.

Smith, D. A., R. A. Locarnini, B. L. Lipphardt Jr., and E. E. Hofmann, Hydrographic data collected aboard RV Nathanial B. Palmer, March-May 1993, 215 pp., CCPO Tech. Rep. 93-04, Old Dominion Univ., Norfolk, Va., 1993a.

Smith, D. A., R. C. Smith, and D. Menzies, Hydrographic data collected aboard RV Nathanıal B. Palmer, MarchMay 1993, 265 pp., CCPO Tech. Rep. 93-05, Old Dominion Univ., Norfolk, Va., 1993b.

Smith, D. A., E. E. Hofmann, J. M. Klinck, and C. M. Lascara, Hydrography and circulation of the west Antarctic Peninsula continental shelf, Deep Sea Res., in press, 1998

Smith, N., and R. Tréguer, Physical and chemical oceanography in the vicinity of Prydz Bay, Antarctica, in Southern Ocean Ecology: The BIOMASS Perspective, edited by S. Z. El-Sayed, pp. 25-43, Cambridge Univ. Press, New York, 1994.

Smith, R. C., C. R. Booth, and J. L. Star, Oceanographic bio-optical profiling system, Appl. Opt., 23, 2791-2797, 1984.

Smith, R. C., K. S. Baker, W. R. Fraser, E. E. Hofmann, D. M. Karl, J. M. Klinck, L. B. Quetin, B. B. Prezelin, R. M. Ross, W. Z. Trivelpiece, and M. Vernet, The Palmer LTER: A long-term ecological research program at Palmer Station, Antarctica, Oceanography, 8, 77-86, 1995.

Stammerjohn, S. E., and R. C. Smith, Spatial and temporal variability in the west Antarctic Peninsula sea ice coverage, in Foundations for Ecological Research West of the Antarctic Peninsula, Antarct. Res. Ser., vol. 70, edited by R. M. Ross et al., pp. 81-104, AGU, Washington, D. C., 1996.

Toole, J. M., Sea ice, winter convection and temperature minimum layer in the Southern Ocean, J. Geophys. Res., 86, 8037-8047, 1981.

Trenberth, K. E., W. G. Large and J. G. Olson, The mean annual cycle of global ocean wind stress, J. Phys. Oceanogr., 20, 1742-1760, 1990. 
UNESCO, Algorithms for computation of fundamental properties of seawater Tech. Pap. Mar. Sci., 44, 53 pp., Paris, 1983

Waters, K. J., and R. C. Smith, Palmer LTER: A sampling grid for the Palmer LTER program, Antarct. J. U. S., 27, 236-239, 1992.

White, W. B., and R. G. Peterson, An Antarctic circumpolar wave in surface pressure, wind, temperature and sea-ice extent, Nature, 380, 699-702, 1996.
J. M. Klinck, CCPO, Crittenton Hall, Old Dominion University, Norfolk, VA 23529. (e-mail: klinck@ ccpo.odu.edu)

(Received January 17, 1997; revised November 20, 1997; accepted December 1, 1997.) 